MORPHOMETRIC STUDIES AND A COMPLEX AIRWAY EVALUATION PANEL FOR OBJECTIVE AND RELIABLE ASSESSMENT OF LARYNGO-TRACHEAL STENOSIS SURGERY

Ph.D. Thesis

Balázs Sztanó M.D.

Department of Oto-Rhino-Laryngology, Head and Neck Surgery University of Szeged

University of Szeged, Faculty of Medicine Clinical Medical Sciences Doctoral School Ph.D. Program:

Clinical and Experimental Research for Reconstructive and Organ-sparing Surgery

Program director: Prof. Dr. Jenő Czigner D.Sc. Supervisor: Prof. Dr. László Rovó 
PUBLICATIONS related to the PhD Thesis

I. Rovó L., Venczel K., Torkos A., Majoros V., Sztanó B., Jóri J.

Endoscopic arytenoid lateropexy for isolated posterior glottic stenosis

Laryngoscope. 2008 Sep;118(9):1550-5

Impact factor: 1,877

II. Sztanó B., Rovó L., Jóri J.

Kisgyermekkori kongenitális eredetü elülső commissura szükület megoldása endoszkópos technikák kombinálásával

(Endoscopic management of congenital anterior glottic stenosis)

Fül-Orr-Gégegyógyászat 2009; 55(3): 121-125

III. Rovó L., Venczel K., Torkos A., Majoros V., Sztanó B., Jóri J.

Az izolált hátsó commissura hegesedés megoldása endoszkópos kannaporc lateropexiával

(Endoscopic arytenoid lateropexy for isolated posterior glottis stenosis)

Fül-orr-gégegyógyászat 2009; 55(1):34-40

IV. Sztanó B., Torkos A., Rovó L.

The combined endoscopic management of congenital laryngeal web Int J Ped Otorhinolaryngology 2010;74: 212-215

Impact factor: 1,118

V. Rovó L, Sztanó B, Tálosi Gy, Rácz K, Majoros V, Czigner J, Túri S, Jóri J

Gyermekkori subglotticus és tracheaszükületek szegmentreszekcióra épülő egy lépésben történő megoldása

(One-stage segmentresection for pediatric subglottic and trachea stenoses)

Gyermekgyógyászat, 2010;61(2):54-59

VI. Rovó L, Madani S, Sztanó B, Majoros V, Smehák G, Szakács L, Jóri J.

A new thread guide instrument for endoscopic lateropexy

Laryngoscope. 2010 Oct;120(10):2002-7 
Impact factor: 2,018

VII. Sztanó B., Szakács L., Smehák Gy., Madani S., Jóri J., Rovó L.

Hangréstágító mütétek hatásosságának vizsgálata cadaver gégéken morphometriás módszerrel I. - a hátsó commissura konfigurációjának változása

(Surgical anatomical morphometric studies in cadaver larynges - the posterior commissure)

Fül-orr-gégegyógyászat 2011; 57(2):48-53

VIII. Rovó L, Madani S, Sztanó B, Majoros V, Smehák Gy, Szakács L, Jóri J

Új, fonalvezető eszköz az endoszkópos arytenoid lateropexia céljára (referátum).

(New endolaryngeal thread guide instrument designed for endoscopic arytenoid lateropexy)

Fül-Orr-Gégegyógyászat 2011; 57(1):47-48

\section{CITABLE ABSTRACTS}

I. Sztanó B, Rovó L, Smehák G, Czigner J, Jóri J

Endoscopic arytenoid lateralisation of scarry fixed vocal cords

EUFOS 2007 6th European Congress of Oto-Rhino-Laryngology Head and Neck

Surgery June 30th - July 4Th 2007 Vienna/Austria

Eur Arch Otorhinolaryngol (2007) (Suppl 1) 264:S101 HP 100

Impact factor: 0.648

II. B. Sztanó, L. Szakács, G. Smehák, S. Madani, L. Rovó

A morphometric cadaver study for the improvement of simple suture vocal cord lateralisation

8th Congress of the European Laryngological Society, Vienna

Eur Arch Otorhinolaryngol (2010)

Impact factor: 1,167

III. L. Rovo, S. Madani, L. Szakacs, B. Sztano, J. Jori

New instruments for endoscopic arytenoid lateropexy 
8th Congress of the European Laryngological Society, Vienna

Eur Arch Otorhinolaryngol (2010)

Impact factor: 1,167

IV. G. Smehak, L. Szakacs, B. Sztano, A. Szamoskozi, L. Rovo

Is a deteriorated voice quality necessary after glottis enlarging procedures?

8th Congress of the European Laryngological Society, Vienna

Eur Arch Otorhinolaryngol (2010)

Impact factor: 1,167

PUBLICATION not directly related to the PhD thesis:

I. Kecskés G, O’Reilly B, Rovó L, Sztanó B, Viharos L, Kiss JG, Jóri J

A glasgow-i arcidegbénulás elemző skála - új, objektív értékelési lehetőség

(Clinical assessment of a new comuterised objective method of measuring facial palsy)

Fül-Orr-Gégegyógyászat 2010;56(4): 234-241, 2010 
ABBREVIATIONS

BVCI Bilateral Vocal Cord Immobility

BVCP Bilateral Vocal Cord Palsy

PGS Posterior Glottic Stenosis

EAL Endoscopic Arytenoid Lateropexy

VCL Vocal Cord Laterofixation

S

Schobel's External Arytenoid Lateropexy

TC

Transverse Cordotomy

LTR:

Laryngo-tracheal Reconstruction

PCTR

Partial Crico-tracheal Resection

PIF

Peak Ispiratory Flow

FIV1

Forced Inspired Volume in one second

FIVC

Forced Inspiratory Vital Capacity

PEF

Peak Exspiratory Flow

FEV1

Forced Exspired Volume in one second

FEVC

Forced Exspiratory Vital Capacity

QoL

Quality of Life

Mit-C

Mitomycin-C 


\section{CONTENT}

1. INTRODUCTION 1

1.1. SURGICAL ANATOMICAL MORPHOMETRIC STUDIES 3

1.2. EVALUATION OF THE EFFICACY OF THE SPIROMETRIC PARAMETERS IN AIRWAY STENOSIS

1.3. A SUBJECTIVE 'QUALITY OF LIFE' QUESTIONNAIRE FOR THE EVALUATION OF PEDIATRIC STENOSES

2. AIMS OF THE THESIS

3. METHODS AND SUBJECTS

3.1. SURGICAL ANATOMICAL MORPHOMETRIC STUDIES

3.1.1. Comparison of endoscopic glottis enlarging techniques on cadaver larynges

3.1.1.1.Suture lateralization procedures

3.1.1.2. Irreversible resection procedures

3.2. EXPERIMENTAL MODEL FOR THE EVALUATION OF THE EFFICACY OF THE SPIROMETRIC PARAMETERS IN AIRWAY STENOSIS

3.2.1. Evaluation of normal inspiratory spirometric indices

3.2.2. Evaluation of the deviation of the spiromeric indices in different grades of stenoses

3.2.2.1. The statistical work-up

3.3. PIF AS AN INDICATOR OF THE IMPROVEMENT IN A NEWLY DESIGNED SURGICAL PROCEDURE FOR GLOTTIS STENOSIS

3.3.1. The applied surgical method for PGS 15

3.3.1.1.Patients $\quad 15$

3.3.1.2.Surgical technique and postoperative treatment 16

$\begin{array}{ll}\text { 3.3.1.3.Evaluation of the clinical results } & 18\end{array}$ 
3.4. A SUBJECTIVE 'QUALITY OF LIFE' QUESTIONNAIRE FOR THE $\begin{array}{ll}\text { EVALUATION OF PEDIATRIC STENOSES } & 19\end{array}$

3.4.1. A hungarian adaptation of Lausanne Quality of Life Questionnaire

3.4.2. The applied surgical techniques for the improvement of pediatric $\begin{array}{ll}\text { airway in this study } & 20\end{array}$

3.4.2.1. The endoscopic complex management of laryngeal web 20

$\begin{array}{lll}\text { 3.4.2.1.1. Patients } & 21\end{array}$

3.4.2.1.2. Surgical technique 21

3.4.2.2. Pediatric airway surgery for laryngo-tracheal stenoses 23

3.4.2.2.1. Tracheal resection 24

3.4.2.2.2. Partial crico-tracheal resection 25

3.4.2.2.3. Combined one-stage laryngo-tracheal reconstruction with crico-tracheal resection 26

$\begin{array}{lll}\text { 3.4.2.2.4. Patients } & 26\end{array}$

3.5. A COMPLEX EVALUATION PANEL FOR LARYNGO-TRACHEAL STENOSES IN CASES OF REVISION SURGERY 27

4. RESULTS

28

4.1. SURGICAL ANATOMICAL MORPHOMETRIC STUDIES 28

4.1.1.Comparison of endoscopic glottis enlarging techniques 28

4.2. EXPERIMENTAL MODEL FOR THE EVALUATION OF THE EFFICACY OF THE SPIROMETRIC PARAMETERS IN AIRWAY STENOSIS 29

4.2.1. Evaluation of normal inspiration spirometric parameters 29

4.2.2.1. Factor analysis and correlation matrix 30

4.2.2. Evaluation of the deviation of the spiromeric parameters in different grades of stenoses 
4.3. RESULTS OF OUR ENDOSCOPIC METHOD DESIGNED FOR THE TREATMENT OF PGS

4.4. A SUBJECTIVE 'QUALITY OF LIFE' QUESTIONNAIRE FOR THE EVALUATION OF PEDIATRIC STENOSES

4.4.1. The endoscopic complex management of laryngeal web 34

4.4.2. Pediatric airway surgery for laryngo-tracheal stenoses

4.5. A COMPLEX EVALUATION PANEL FOR LARYNGO-TRACHEAL STENOSES - REVISION SURGERY

5. DISCUSSION

5.2.EXPERIMENTAL MODEL FOR THE EVALUATION OF THE EFFICACY OF THE SPIROMETRIC PARAMETERS IN AIRWAY STENOSIS

5.3. ENDOSCOPIC ARYTENOID LATEROPEXY FOR THE POSTERIOR GLOTTIC STENOSIS

5.4. A SUBJECTIVE 'QUALITY OF LIFE' QUESTIONNAIRE FOR THE EVALUATION OF PEDIATRIC STENOSES

5.4.1. The endoscopic complex management of laryngeal web

4.2.3. Pediatric airway surgery for laryngo-tracheal stenoses

5.5. A COMPLEX EVALUATION PANEL FOR LARYNGO-TRACHEAL STENOSES - REVISION SURGERY 
6.2. EXPERIMENTAL MODEL FOR THE EVALUATION OF THE EFFICACY OF THE SPIROMETRIC PARAMETERS IN AIRWAY STENOSIS

6.3. PIF AS AN INDICATOR OF THE IMPROVEMENT IN A NEWLY DESIGNED SURGICAL PROCEDURE FOR GLOTTIS STENOSIS

6.4.A SUBJECTIVE 'QUALITY OF LIFE' QUESTIONNAIRE FOR THE EVALUATION OF PEDIATRIC STENOSES

8. REFERENCES

9. APPENDIX 


\section{INTRODUCTION}

The treatment of upper airway stenoses is considered to be one of the most difficult fields in laryngology. Until 1960s diphteria, tuberculosis, syphilis and external were the major etilogogical factors, but the current medical treatments have significantly decreased the incidence of these diseases. In the past decades the increasing number of medical interventions has induced an increasing number of iatrogenic laryngo-tracheal stenoses

The complexity of the question arises from the widely different origins of these phenomens which ranges from congenital malformations through the autoimmune diseases to iatrogenic causes such as prolonged intubation and surgical failures. The extension, the site and the severity of the stenoses means another problem, not taking apart from the multiple physiological function, which means nowadays the most studied topic of the glottic malformations.

It is not a surprise that according to the PubMed database 4934 publications have been listed under only the one label, the 'upper airway obstruction' until 2012. In the 100-year-old history of this field several important works of Hungarian authors (Rethi, Lichtenberger) are found $(1,2)$. In the 1990s only for the treatment of glottic stenoses more than 70 different surgical solutions were advised according to Pytel at al (3). Many of these methods were based on re-interpretation of old 'ideas', by the tremendous technical improvement of laryngology. The laryngo-tracheal and tracheal stenoses mean also a complex problem to the surgeon; their treatment has just been improved dynamically in the past decades.

Until the 1970s tracheostomy had been the only effective treatment for severe laryngotracheal stenoses. In 1974 Evans described the first method of real treatment: laryngotracheoplasty (LTP) resolutitionizing the management of pediatric laryngo-tracheal stenosis (4). This consisted of expanding the subglottic lumen by means of a layngofissure continued into a castellated incision made in the cricoid and upper tracheal rings. Since 1978 Cotton's laryngotracheal reconstruction (LTR) has been believed to provide the best results for the problem $(5,6,7)$. This operation involves augmentation of the laryngotracheal complex by anterior and posterior midline incision of the cricoid and thyroid cartilages with insertion of costal cartilage grafts to expand the airway $(8,9,10,11,12)$. Traditionally, endoscopic methods were thought to have only limited role in the treatment, especially in mild cases. No single scar dissection provides satisfactory results because of the restenosis. In case of glottic stenoses the use of stent, keel, mucosal flap may improve the results $(13,14,15,16)$. The 
topically used antiproliferative Mitomycin-C that inhibits RNA and protein synthesis may be effective as well $(17,18,19)$.

As it was written before the solution of a stenosis means still a great dilemma; it is really hard to choose the most suitable method for the patient out of several different surgical methods. This choice is often based on the working team's experiences and traditions, but sometimes unfortunately not the 'ideal' technique is applied. According to the consultation to other workgroups and our own experiences in this field no real surgical protocols have been introduced. One of the main couses is the lack of evaluation panels being able to compare the results of different methods. The real efficacy of the surgical solutions is really hard to evaluate, but the improvement of the breathing can be considered to be the key factor. Obviously, the choosing the best from the armatory of the above mentioned surgical methods for the different stenoses, the working-up generally applicable surgical protocol must be based on a correct, objective, reliable tests which allows the measurement of the airway improvement.

However, the relatively hidden position of the studied organs makes difficult the direct measurements of the airway improvement. The need for general anaesthesia as it is suggested by Cotton and Myers (20) arises severe ethical question for a follow-up measurement, Radiation explosure and the costs of the imaging techniques also limitate the application of these methods. In contrast with the pulmonary diseases where the expiratory airway fuction parameters are well described, the role and even the ranges of the inspiratory parameters in extrathoracal stenoses are confused in the literature, which makes the comparison difficult. The same confusion can be found in the questionnaires designed for Quality of Life. Finally, the case numbers of the presented studies are generally too low for a correct statistical analysis.

I have been working in the Department of Otorhinology, Head and Neck Surgery, University of Szeged since 2002. I have joined to the 'airway stenosis surgical team' under the supervision of Professor Czigner, Professor Jóri and Professor Rovó. I took part in several operations of different types of stenoses. In previous works our team has already suggested an evaluation panel for the other important aspect of these surgeries, the phoniatric outcomes (21). One of my main tasks was to perform the pre- and postoperative examinations for the airway improvement of these surgeries which was compulsory for publishing our newly designed or modified surgical methods of this topic. 
As I have pointed out, this evaluation means a really complex question, which involves different investigating methods:

- cadaver morphometric studies,

- evaluation of the functional spirometric tests,

- evaluation of Quality of Life Questionnaires.

My aim of the thesis and my clinical work focused on working-up assessment methods and a reliable evaluation panel designed for the relatively simple comparison of the different surgical techniques which might help to perform a protocol for the management of the stenotic airway.

\subsection{SURGICAL ANATOMICAL MORPHOMETRIC STUDIES}

The posterior commissure involves the dorsal third of the vocal cords, the cricoid lamina, the arytenoid cartilages and the interarytenoid area with the interarytenoid muscles and their covering mucosa $(22,23)$. Injury here may lead scar and to posterior glottic stenosis (PGS), limiting normal glottic motion by resulting in one or both arytenoid cartilages becoming fixed into their adducted position. Bilateral fixation commonly causes severe dyspnea absent a tracheostomy. In the past decades prolonged intubation (24) - due to the increase of patients undergoing assisted ventilation - has become the most frequent cause of PGS occurring in approximately $1 \%$ of cases. (25). The effect is a pseudo-paralysis of normally innervated vocal cords $(11,24,26)$.

The moderate to severe dyspnea caused by bilateral vocal cord fixation generally requires surgical intervention, depending on the grade of the stenosis (e.g. BogdassarianOlson classification (24)), and the experience of the surgical team. Several different procedures have been introduced $(3,27,28)$, but the treatment of this hazardous vocal fold fixation still pose a great challenge even today. A simple scar transection provides limited and short lived success even in mild cases because of the destruction of the deeper layers of the posterior glottis and cricoarytenoid joints. Also, the connecting raw wound surfaces increase the risk for restenosis. This is also a well-known problem of other widely used procedures such as the transverse cordotomy (TC) $(29,30)$ or the arytenoidectomy (A) (31). What's more, due to the originally damaged state of the posterior commissure, the effect of these procedures 
may be to worsen the stenosis. Eckel et al in a consecutive series of 32 bilateral vocal cord mechanical fixations could achieve only $44 \%$ decannulation rate with these methods (32). However, by open techniques this results could be improved to $100 \%(1,15,32)$, but tracheostomy might have to be sustained for weeks and many of these patients had to face a significant deterioration of laryngeal function and voice. By contrast, in our earlier studies (I,VI) we presented a consecutive series of 42 patients with different grades of stenosis; all were treated successfully by a minimally invasive endoscopic method. Following to the resection of fixating scars, and mobilisation of the cricoarytenoid joints and a temporary endoscopic bilateral arytenoid lateropexy. This approach provided not only a significant airway improvement but a functional larynx secondary to vocal cord motion recovery. The rate of success was found to be more favourable compared to other procedures. Many authors have previously suggested a stent, a keel $(1,14,15,33,34)$ or mucosal flap (16) keeping open the posterior glottis space after the scar resection, but these intervention succeeded in lowgrade stenosis and also often require tracheostomy.

The purpose of our method is to provide the largest possible space in the posterior commissure, thus keeping the wounds apart until healing (I,III,VI,VIII,35,36,37,38). This way the chance for developing a fibrin cicatrix can be diminished. Moreover, the durable separation of the opposing wound surfaces over a period of weeks counters the contraction forces of the scarring process due to the myofibroblasts in early healing (39). The application of Mitomycin-C also might have a further beneficial effect (18).

„Largest space” means maximal inspiratory abduction of the arytenoid cartilage relative to the crcoarytenoideal joint anatomy. Our surgical method, the 'arytenoid lateropexy', which is based on this physiological abduction, confers a better effect than the other endoscopic methods. The effectiveness of different glottis enlarging techniques described in the literature cannot be analysed easily. The case numbers are generally so low as to make it hard to study common groups. Only one procedure can be performed on one patient, so the different methods cannot be reasonably compared in clinical practice. The aim of this study which was based on a large number of cadaver larynges was to avoid this limitation. By assessing the effectiveness of different endoscopic procedures, each performed on the same cadaver larynx, an objective comparison was made possible. This has never been done to date. 


\subsection{EVALUATION OF THE EFFICACY OF THE SPIROMETRIC PARAMETERS IN AIRWAY STENOSIS}

Since Borelli first measured lung volumes in 1679, the development of lung function tests has evolved tremendously. Further exploration of the principles of lung function tests, improvements in instrumentation and methodology, and the promotion of clinical applications have continued since the 1970s. Lung function tests have become an indispensable tool for the clinical evaluation of respiratory health and disease. In recent years, the establishment of guidelines for performing lung function tests has given these tests even wider clinical application in different clinical scenarios.

Spirometry is a relatively simple, non-invasive method for measuring the flow and volume of air from full lung inflation as a function of time, using forced manoeuvres It is widely accepted as a clinical tool for diagnosing obstructive, restrictive or mixed ventilatory defects. It plays an essential role in the diagnosis and management of respiratory diseases, especially asthma and chronic obstructive pulmonary disease (COPD) (40,41).

Spirometry may be applied also in cases of extrathoracal stenoses, such as glottic and subglotto-tracheal stenoses $(42,43)$.

Reviewing of the literature it is clear, while the changing and the normal range of expiratory parameters is well-discuted, and means the basis of diagnosis of diseases of the lower airways, but the inspiratory parameters, which mainly can be connected to the upper airway problems have no this sophisticated work-up. So we focused on clarifying these correlations.

\subsection{A SUBJECTIVE 'QUALITY OF LIFE' QUESTIONNAIRE FOR THE EVALUATION OF PEDIATRIC STENOSES}

In 2005 Monnier's team published a simple Lausanne 'Quality of Life' Questionnaire assessing the functional outcomes of the surgery in terms of breathing, voice, swallowing, and overall satisfaction (44).

The following items were rated by the patients or their parents by using the scales as indicated: dyspnea (grade $0_{\text {_ }}$ absent to grade IV at rest); noisy breathing (grade $0_{-}$absent to grade 3 _ very noisy breathing even at rest); coughing (grade $0_{\text {_ }}$ absent to grade II _ frequent

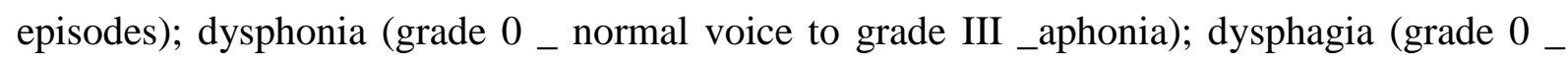


absent to grade III _ nasogastric tube feeding); and global satisfaction (grade 1 totally satisfied to grade 4 - totally unsatisfied). In all parameter lower grades means better condition.

Monnier applied this tool in patients after pediatric laryngeal reconstruction $(44,45)$. The simple questions are answered by the parents of the patients. The results of the operations in early childhood may be evaluated hardly, the endoscopic examinations can be performed only in general anaesthesia, which limits its availability. Functional spirometric tests can not be done, so this simple subjective self-evaluation test may have a really important role in describing the functional outcomes.

Our clinic was one of the first departments introducing a new concept of pediatric stenosis surgery in Hungary. The modificiation of some standard surgical techniques and the combination of different methods led to the decrease of morbidity and inconvieniency of the interventions. Our new concept could be performed in newborns as well. These pediatric cases gave a good opportunity to apply this Lausanne QoL Questionnaire and to assess its valuability. 


\section{AIMS OF THE THESIS}

1. Cadaver morphometric studies were designed to compare objectively the efficacy of suture lateralizing and irreversible resection glottis enlarging techniques for the treatment of bilateral vocal cord immobility.

2. Evaluation of spirometric parameters used for the measurements the results of airway surgeries.

1. to examine the normal range of inspiratory parameters

2. to find the most 'sensitive' parameters for airway stenoses

3. In our clinic a new, minimally invasive endoscopic method was introduced for the treatment of posterior glottic stenoses. The correlation between pre- and postoperative Peak Inspiratory Flow and the clinical outcomes.

4. Evaluation of the Lausanne Quality of Life Questionnaire in patients with difficulties performing spirometric tests. The role of subjective assessment in pediatric airway sugery.

5. Creation of a standard protocol contaning objective spirometric and subjective 'Quality of Life' measurements for the evaluation of upper airway stenosis surgery, which can be used in the everyday practice and simple enough to be adopted in an ordinary Hungarian ENT department. 


\section{METHODS}

\subsection{SURGICAL ANATOMICAL MORPHOMETRIC STUDIES}

A hundred freshly excised cadaver larynges (50 male and 50 female) were analysed. For a better view of the glottic area the epiglottis and the vestibular folds were removed (Fig 1) Larynges were inserted into a fixation device and secured with three screws along the cricoid cartilage which resisted deformation caused by the screws. The screws were always in the same position in each larynx. High-resolution digital photos were taken from a top view by Nikon D60 camera fixed on a tripod (with Nikon 18-55/F3.5-5.6 AF-S DX G VR lens). The fixation device made it possible to take all photos from a consistent position.

In the first study the effect of different 'simple' suture-based glottis widening techniques on the posterior glottic apperture were measured in 60 larynges (30 male and 30 female). First, the normal cadaveric position of the larynges was documented. Then four different suture lateralisation maneuvers were performed one by one on the left side on each larynx. Typical needle holder and suture materials were used; the readily accessible glottis obviated the need for special instruments.

All procedures were performed according to the techniques described in the literature.

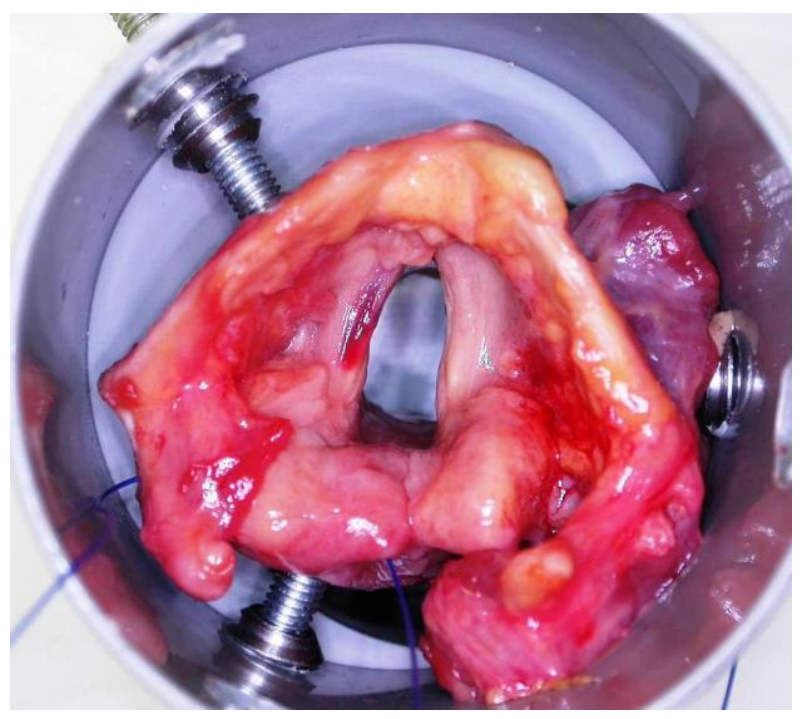

Fig. 1.: A cadaver larynx in the fixation device. The supraglottic parts were removed for a better view 


\subsubsection{Suture lateralisation procedures}

1. Classic vocal cord laterofixation (VCL). The vocal cord is lateralised and fixed by a thread loop inserted on the vocal process or just anterior to it. There are two types: the Lichtenberger's endo-extralaryngeal (46) and the Ejnell's exo-endolaryngeal procedure (47). In this study the suture loop was placed according to Lichtenberger's concept, which allows for a more precise loop formation around the vocal process. (Fig. 2A).

2. Modified vocal cord laterofixation (MVCL). Lichtenberger's later modification was also examined, in which a second thread was inserted a couple of millimetres anteriorly from the original one (15) (Fig. 2B).

3. Endoscopic arytenoid lateropexy (EAL). The arytenoid cartilage was rocked into its maximally abducted position and then a thread loop was placed round the vocal process (I,III) (Fig. 2D).

These minimally destructive procedures were performed on each larynx. They were taken in turns so that the prior surgical technique would not affect the results. The thread loops were positioned into the position described in the original publications, and then knotted on the outer surface of the thyroid cartilage.

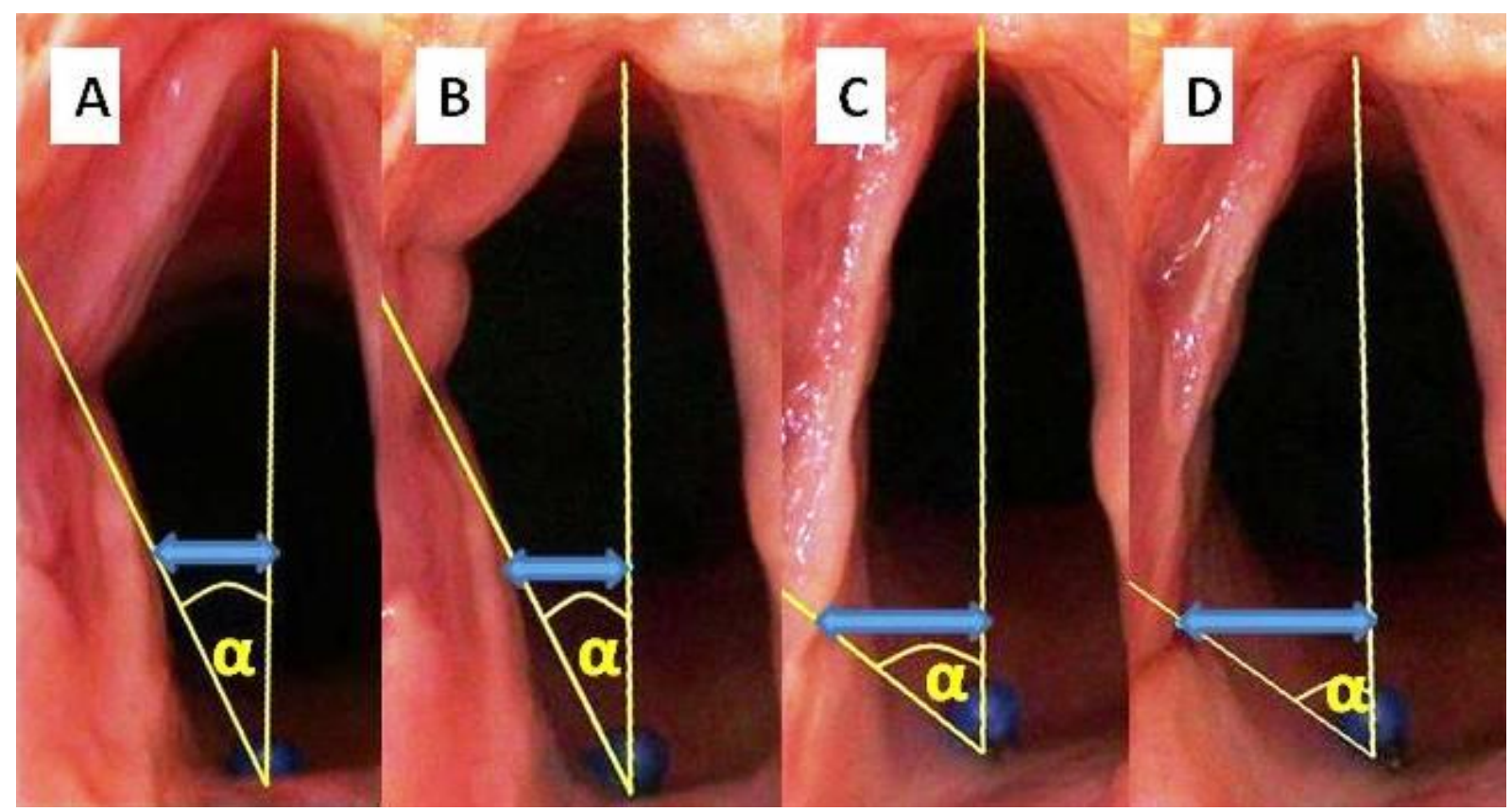

Fig. 2: Four different suture lateralizing techniques performed on the left side of the same cadaver larynx (Larynx No. 18, male 63 Y)

The analysed parameters describing the posterior glottis are signed: the midline - left vocal process distance (blue arrows), the angle between vocal process - posterior commissure line and midline (yellow $\alpha$ )

A: VCL 1 suture, B: VCL 2 sutures, C: Schobel's method, D: EAL 
4. Schobel's external lateralisation procedure (S). As the control group of the endoscopic methods, this one was performed last, because it causes a greater amount of tissue damage. The arytenoid cartilage is tilted and fixed laterally with two submucousally placed sutures; one is knotted on the posterior margin and the second is placed round the superior horn of the thyroid cartilage (3,28). (Fig. 2C)

\subsubsection{Irreversible resection procedures}

In the next part of the study, the transverse cordotomy (TC) was compared to the EAL on 20 cadaver larynges; and finally the total arytenoidectomy (A) was compared to the EAL on 20 different larynges. Because of the irreversibility of these procedures two subgroups were created. Prior to the surgery the supraglottic parts were also removed and the same instrumentation was used for the fixation and documentation.

1. The Dennis and Kashima Transverse cordotomy (TC) (30). An incision was made at the vocal process, and a wedge-shaped defect was created by the removal of the middle third of the vocal cord. (Fig 3)

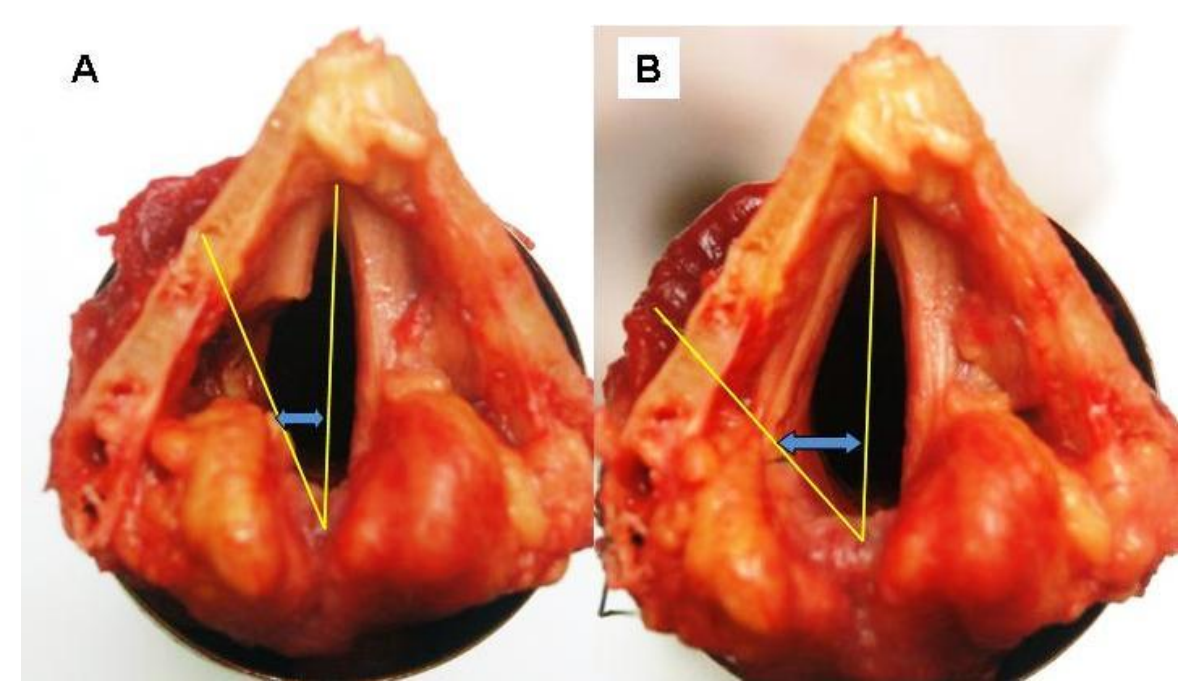

Fig. 3: Transverse cordotomy (A) and EAL (B)

(Larynx No. 68, male, 74Y)

The analysed parameters describing the posterior glottis are signed: the midline - left vocal process distance (blue arrows),

the angle between vocal process - posterior commissure line and midline (yellow) 
2. The Ossoff Total arytenoidectomy (A) (48). In order to simplify the procedure, the left arytenoid was completely removed along with the surface mucosa. In common surgical practice, the medial mucosa is normally kept in place, but we wanted to evaluate the theoretical maximum efficacy of the surgical method so we removed it. In this study cold instruments were used for the procedure. (Fig. 4)

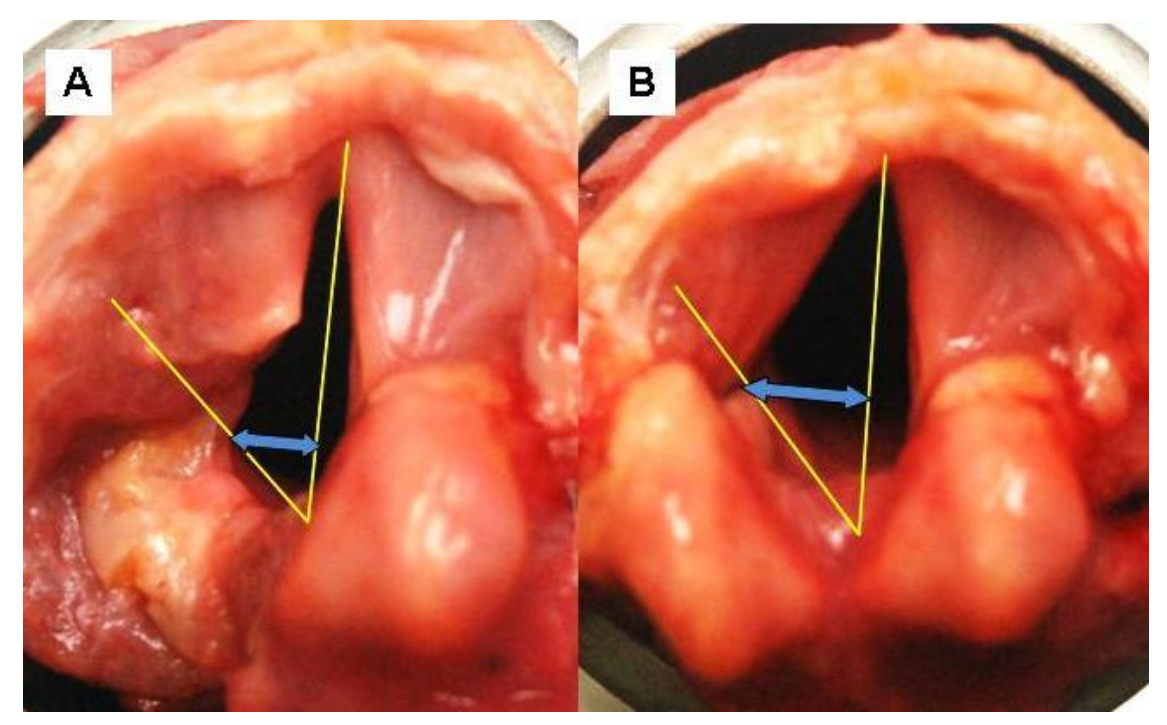

Fig. 4: Arytenoidectomy (A) and EAL (B)

(Larynx No. 83, female, 68Y)

The analysed parameters describing the posterior glottis are signed:

the midline - left vocal process distance (blue arrows),

the angle between vocal process - posterior commissure line and midline (yellow)

Digital image analysis

'Image J' digital picture analyzer software was applied to measure the chosen parameters describing the posterior commissure: in the plane perpendicular to the mediansagittal plane of the larynges, the distance between the left vocal process and sagital midline of larynx was measured. Then, the angles between the long axis of vocal process, the posterior commissure midpoint and laryngeal median-sagittal line were measured (Fig 2) In the 20 larynges treated with arytenoidectomy, the furthest point of the gained glottic area (for distance measurement) and the most posterior point of the left vocal cord (for the angle) were chosen. The results were statistically analyzed by Student-t-test. 


\subsection{EXPERIMENTAL MODEL FOR THE EVALUATION OF THE EFFICACY OF THE SPIROMETRIC PARAMETERS IN AIRWAY STENOSIS}

The pirometric examination is highly dependent on patient cooperation and effort, so spirometry can only be used on children old enough to comprehend and follow the instructions given (6 years old or more), and only on patients who are able to understand and follow instructions.

The meneuver requires maximal effort from the patient and it takes time to perform quality spirometry. It is essential the procedure is carefully and clearly explained and to actively coach and motivate the patient to perform maximally. The performance of spirometry while seated upright in a chair is preferable to standing as this is the most stable position should the patient experience dizziness during the test. The key steps are to urge the patient to breathe in fully (the lungs must be absolutely full, seal the lips around the mouthpiece and immediately blast the air out as fast and as far as possible until the lungs are completely empty. Then breathe in fully again as fast and as far as possible. The test is repeated until three acceptable results are obtained. The best results, the highest values are chosen.

\section{The measured spirometric indices:}

- FIVC (Forced Inspired Vital Capacity) is the maximum volume of air that can be inspired during a single inspiratory manoeuvre.

- FIV1 (Forced Inspired Volume in one second) is the volume of air that can be forcefully inspired int he first second of the FIVC manouevre.

- PIF (Peak Inspiratory Flow) is the largest expiratory flow achieved during the FVC manoeuvre.

- FVC (Forced Vital Capacity) is the maximum volume of air that can be expired during a single expiratory manoeuvre using maximal effort initiated following a full inspiration.

- FEV1 (Forced Expired Volume in one second) is the volume of air that can be forcefully expired in the first second of the FVC manoeuvre. It is a measure of how quickly full lungs can be emptied.

- PEF (Peak Expiratory Flow) is the largest expiratory flow achieved during the FVC manoeuver. 


\subsubsection{Evaluation of normal reference inspiratory spirometric indices}

The normal reference inspiratory spirometric indices were measured. 96 healthy volunteers were devided into 4 groups according to age (under 20, 20-40, 40-60, over 60 years). Each groups contained 12 males and 12 females. The results were statistically analyzed. Schiller Sp-200 spirometer was used in the study (Fig 5.).

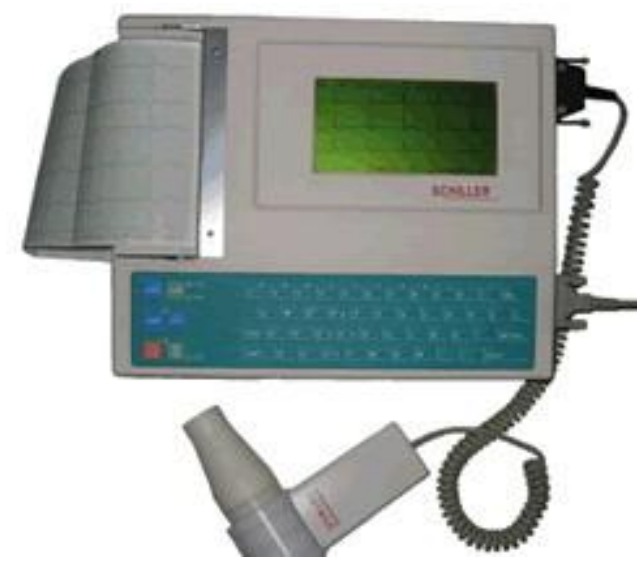

Fig. 5: Schiller Sp-200 spirometer

\subsubsection{Evaluation of the deviation of spirometric indices in different grades of stenoses}

In the next study artificial stenoses were applied, the sensitivity of the spirometric values was assessed. 10 volunteer male and 10 female participated. Artificial stenoses were made, special, $1 \mathrm{~cm}$ long plastic 'strictures' were inserted into the mouthpiece of the spirometer causing a well-defined decrease in the diameter of the mouthpiece which represents different grades of airway stenoses. In each person 4 examinations were performed, first with normal mouthpiece, then 25, 50 and 75\% decreased mouthpieces (Fig 6.).
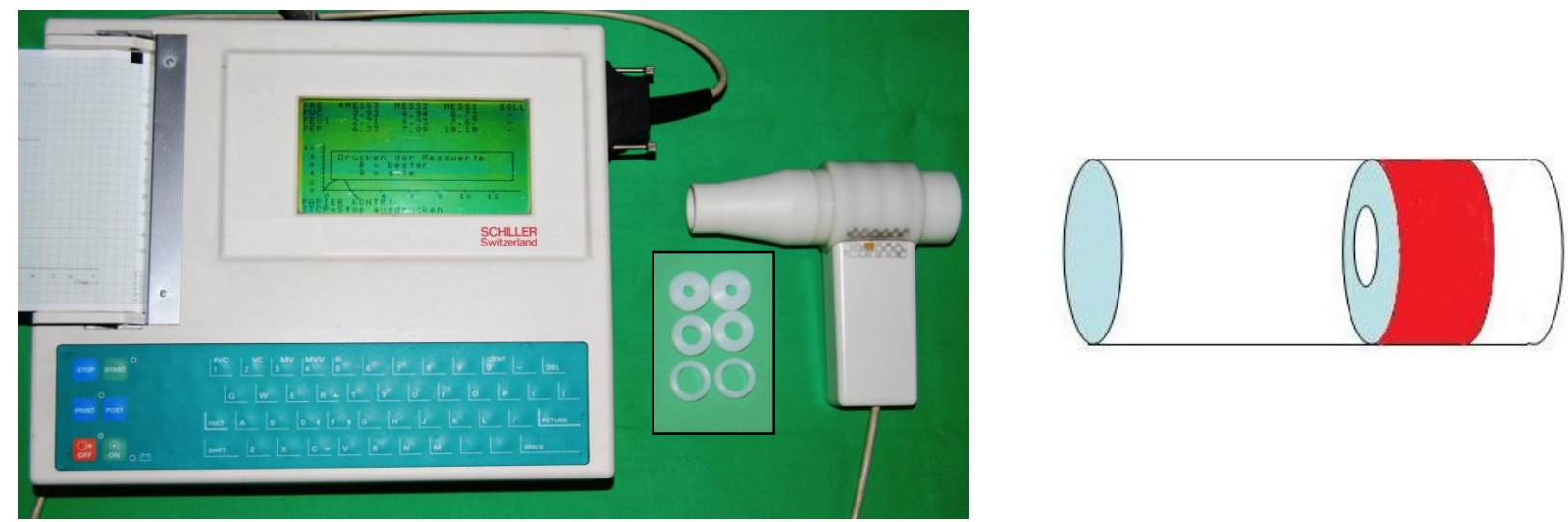

Fig. 6: Artificial 25, 50 and 75\% stenosis inserted into the mouthpiece of spirometer 


\subsubsection{The statistical work-up}

The propotional changes of different spirometric values were analyzed for the determination of the the most sensitive ones.

- Unpaired Student-t-probe was used for the change of the given parameters.

- Factor analysis and correlation was applied to clear the connection of different spirometric parameters.

Factor analysis is a statistical method used to describe variability among observed, correlated variables in terms of a potentially lower number of unobserved variables called factors. In other words, it is possible, for example, that variations in three or four observed variables mainly reflect the variations in fewer unobserved variables. Factor analysis searches for such joint variations in response to unobserved latent variables. The observed variables are modeled as linear combinations of the potential factors, plus "error" terms. The information gained about the interdependencies between observed variables can be used later to reduce the set of variables in a dataset.

\subsection{PIF AS AN INDICATOR OF THE IMPROVEMENT IN A NEWLY DESIGNED SURGICAL PROCEDURE FOR GLOTTIC STENOSES}

Spirometric studies proved that inspiratory indices, especially PIF and FIV1 could be effectively used to evaluate the clinical result. For the treatment of posterior glottic stenosis we introduced a minimally invasive, endoscopic technique. PIF values were applied to assess the postoperative improvement of the airway.

\subsubsection{The applied surgical method for posterior glottic stenosis}

A simple scar transection, however, may only be effective in Bogdassarian-Olson type I stenoses (13). In more severe cases a stent or a keel is inserted $(14,15)$, or coverage of the surgical defects by a mucosa flap graft (16) via external or endolaryngeal approach is used to prevent restenosis. In cases of higher grade (type III-IV) stenoses a posterior cricoid graft is suggested $(8,34)$. The graft and the disruption of the anterior commissure place the voice quality at risk (13). Donor site morbidity means further problems (49). Application of 
endoscopic partial or complete arytenoidectomy $(31,50)$, or transverse cordotomy $(51)$, is to be carefully considered, as irreversible damage to laryngeal function can occur. What's more, due to the originally damaged state of the posterior commissure, the success of these procedures may be limited in the long run (50,52). Proton-pump inhibitors (53) or fibroblastinhibiting Mit-C administered into the lesion may be applied as an adjuvant measure (18).

One of the disadvantages that even the most successful procedures share is that the temporary tracheostomy might have to be sustained for a longer period of time. This can be avoided with functionally adequate outcomes in cases of mild to moderate stenoses (type IIII) if after scar excision an endoscopic simple suture vocal cord laterofixation is performed and sustained for a few weeks $(2,52,54)$. However, bilateral intracapsular scarring of the cricoarytenoid joint (type IV) considerably limits the applicability of this method.

\subsubsection{Patients}

From September 1995 to December 2008 fourty-two consecutive patients (16 females, 26 males) were diagnosed and treated for PGS at our department. The ages ranged from 15 to 74 years with a mean of 44 years. The etiology was prolonged intubation in 36 cases.

In order to evaluate the efficacy of the method suggested in higher grade stenoses, the patients were divided into two groups according to the severity of PGS. The first group (Group A) contained less difficult cases in which scarring involved only one (if any) cricoarytenoid joint (Fig. 7A).

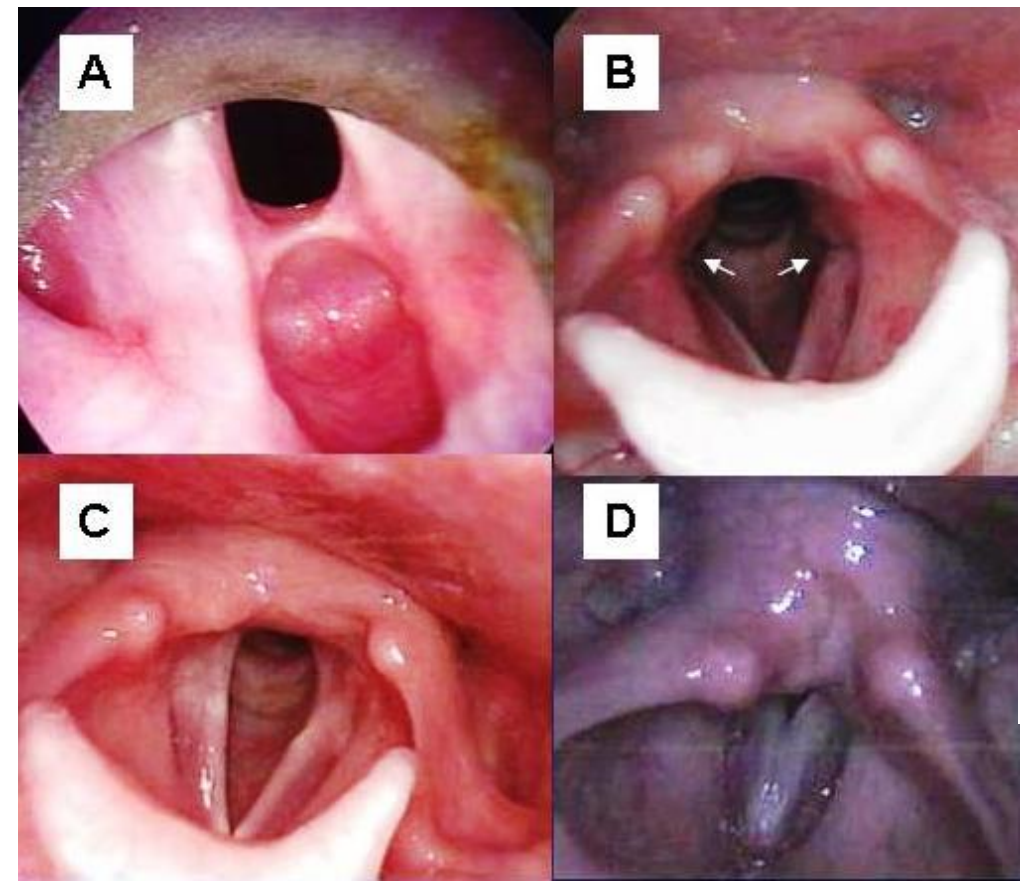

Fig. 7: Type II stenosis

(28-year-old female).

A: scar between the arytenoid cartilages intraoperatively (PIF: $1.2 \mathrm{l} / \mathrm{s}$ ).

B: 2 days after operation the arytenoid cartilages are fixed in an abducted position (PIF: 2.8 1/s).

C: inspiratory picture of the larynx 6 months after removal of the fixing sutures (PIF: 3.2 $1 / s)$.

D: a small closure deficiency detectable only between the vocal processes at phonation (stationary stroboscopy). 
According to the Bogdasarian-Olson classification there was one type I, eight type II and ten type III stenoses in this group. One patient wore a cannula upon admittance.

The second group (Group B) contained 23 more severe cases with both joints immobilized by scarring (type IV, Fig. 8A), 9 of whom had been tracheotomized.

One bilateral arytenoidectomy, one posterior cricoid grafting and six vocal cord laterofixations had been performed either unsuccessfully or with compromised results in 8 patients previously.

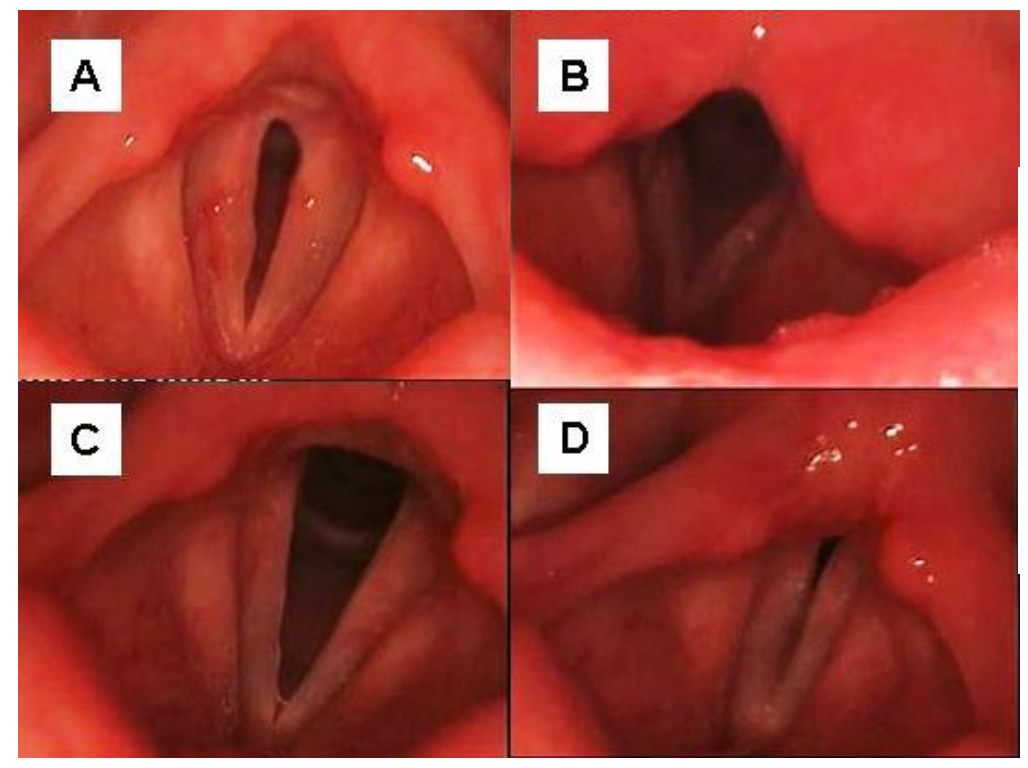

\section{Fig 8: Type IV PGS}

(cannulated 32-year-old female patient). A: preoperative picture.

B: on the first postoperative day the glottis is wide, the patient can be decannulated (PIF: $3.61 / \mathrm{s}$, arrows indicate the sutures).

C: picture of inspiration 6 months after removal of the fixing sutures (PIF: 2.7 1/s).

D: closure is adequate at phonation

\subsubsection{Surgical technique and postoperative treatment}

Surgery was performed under general anesthesia with supraglottic jet ventilation. Approached through a Kleinsasser laryngoscope (Fig. 7A), scars in the interary region were transected with a $\mathrm{CO}_{2}$ laser (10-15 Watts, continuous mode, Lasram Opal-25) under microscopic control, with the posterior mucosa wall preserved. For the sake of better manueverability, during the rest of the operation the larynx was exposed with a Weerda laryngoscope. Afterwards, the mobility of the cricoarytenoid joints was examined by passive mobilization to decide the type of the stenosis.

In cases of joint immobility, a strong, right-angled sabre-shaped scythe designed by our team (Fig. 9A,10) was used for dividing the scars that had developed between the arytenoid and the cricoid cartilage. This instrument enabled the division of the scar in a joint whose plane lay at approximately right angles to the plane of endoscopic exposure, without the need for a widespread laser excision of tissues in the posterior commissure (Fig. 9B and C). In 11 
cases a gelfoam soaked with Mitomycin-C was applied to the opened joint and the posterior commissure (4-5 minutes, $0.4 \mathrm{mg} / \mathrm{ml}$ ).

In order to keep the wound surfaces in the posterior commissure apart, the arytenoid cartilages were fixated in an abducted position (Fig. 9D) with a thread loop (Prolene 1.0) placed around the vocal process. In this site the needle needs to be punched through the dorsal, thicker and in elderly patients often ossified portion of the thyroid cartilage, so a slightly modified, reinforced Lichtenberger's endo-extralaryngeal needle carrier instrument $(33,55)$ was used until 2006. (Fig.10)

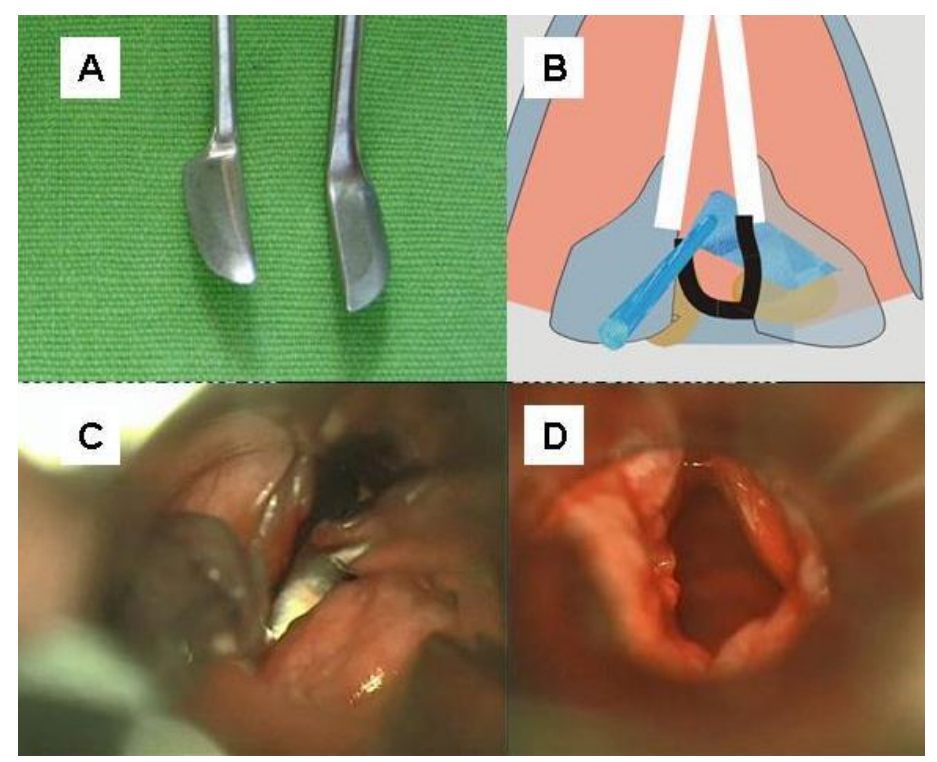

Fig. 9: Mobilization of the arytenoid cartilage at the scarring of the cricoarytenoid joint

(32-year-old female patient with cannula, type IV stenosis, demonstrated on Fig. 8).

A: sabre-shaped blades of the endolaryngeal scythe. To increase rigidity and for the protection of the conus elasticus only one side is sharp (r: right, 1 : left).

B: Schematic figure of the operation (thick black line indicates the margins of the scar tissue removed with the $\mathrm{CO} 2$ laser from between the arytenoid cartilages, the textured area represents the intracapsular scar). $\mathbf{C}$ : the scythe is guided under the vocal process and the scar fixing the arytenoid cartilage is transected along an arch.

D: Intraoperative picture of bilateral arytenoid lateropexy after proper mobilization.

Since that time our newly invented endolaryngeal thread guide instrument (ETGI) could have createed double suture loops (Fig.11, VI).

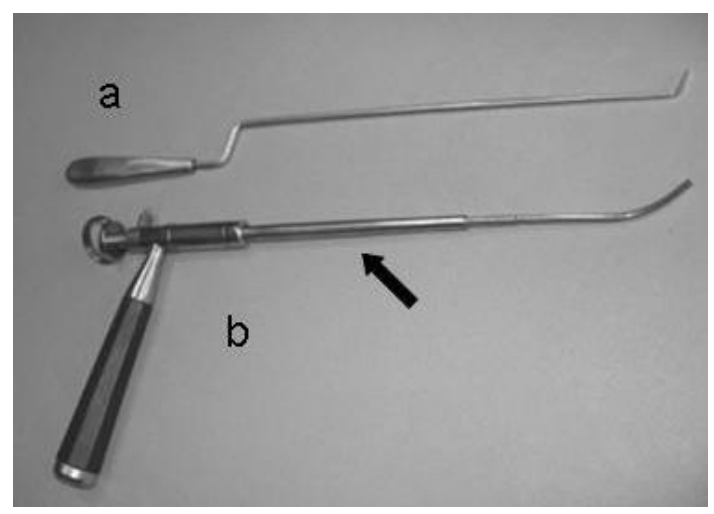

Fig. 10: The rigid, right-angled scythe for an endoscopic transection of scars between the cricoid and arytenoid cartilage (a) and the reinforced Lichtenberger's endoextralaryngeal needle carrier instrument used for arytenoid lateropexy (b, black arrow indicates the steel sheath reinforcing the instrument's stem). 


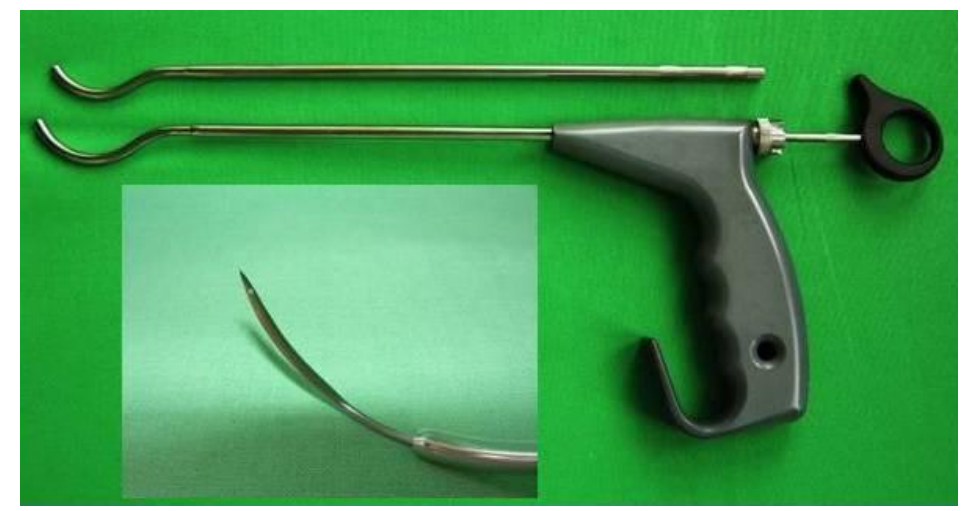

Fig. 11: The endolaryngeal thread guide instrument (ETGI)

Different size of the steel pipe stem allows its pediatric application

Small picture: The built-in, movable, curved blade in a pushed-out pisition with a hole at its tip

This lateralizing maneuver ensured a position that approximated the maximal physiological abduction of the arytenoid cartilage. A $0.5 \mathrm{~cm}$-long skin incision was needed on each side for knotting the thread loop above the prelaryngeal muscles. Lateropexy of the arytenoid cartilage was applied to one side in 3 cases and bilaterally in 39 cases.

In the peri- and postoperative period the patients were administered antibiotics (usually 2x750 mg cefuroxime) and 2x250 mg methylprednisolone for 2-5 days intravenously. The laterofixing sutures were removed via a small skin reincision after 4-8 weeks, once reepithelisation in the posterior commissure was endoscopically confirmed.

\subsubsection{Evaluation of the clinical results}

Patients were followed up every two weeks during the first 2 months, then monthly until the end of the second year. Their laryngeal status was examined with videolaryngoscopy (70 degree rigid Storz endoscope). Spirometric measurements were performed using a Schiller SP-200 spirometer. Peak inspiratory flow (PIF) was documented pre-operatively in patients without tracheostomy, for all patients after the surgery (1-4 days) and finally one year after the surgery. Radiological examination of aspiration was conducted in our first 10 patients at the end of the first week. 


\subsection{A SUBJECTIVE QUALITY OF LIFE QUESTIONNAIRE FOR THE EVALUATION OF PEDIATRIC STENOSES}

\section{'Quality of life' kérdőív \\ felső légúti szű́kületes betegek számára}

Név:

Dg

- $\quad$ Nehézlégzés

1. Nincs

2. Nehéz munkavégzés esetén

3. Enyhe fizikai megerőltetés esetén is

4. Nyugalomban

5. Tracheotomia

- Hangos légzés

1. Nincs, a légzés hangtalan

2. Nehéz munkavégzés eseten hangossá váló légzés

3. Enyhe fizikai megeröltetés esetén is hangos

4. Nyugalomban

5. Tracheotomia

- Köhögés

1. Nincs köhögés

2. Enyhe köhögés

3. Erős köhögés

4. Tracheotomia

- $\quad$ Hang

1. Normális

2. Kis fokú beszédzavar (hangos környezetben nehezebben érthető)

3. Súlyos beszédzavar

4. Aphonia

- $\quad$ Nyelés

1. Normális

2. Kisebb nehézségek, időnkénti félrenyelés

3. Súlyos nyelészavar

- $\quad$ Elégedettség az állapottal

1. Teljesen elégedett

2. Nagyrészt elégedett

3. Kissé elégedetlen

4. Elégedetlen 


\subsubsection{A Hungarian adaptation of Lausanne QoL Questionnaire}

'QoL' Questionnaire was translated, adapted and introduced to our clinical protocol as well. The pre- and postoperative status has been usually evaluated. It was used both retrospectively and prospectively. To assess the results of our previous operations the formulars were sent to the patients' parents. They tried to describe their children's pre- and postoperative status. In the Department of Pediatrics the nurses filled out our formular. Nowadays it is used routinely in case of all stenosis patients, both children and adults.

The Quality of Life Questionnaire was used in our pediatric cases, in which it was a good evaluation tool.

\subsubsection{The applied surgical techniques for the improvement of the pediatric airway in this study}

The following surgical methods were introduced for the treatment of different pediatric upper airway stenoses.

\subsubsection{Endoscopic complex management of laryngeal web}

The primary goals of surgical management of laryngeal webs are to provide patent airway and to achieve a good voice quality. In the past tracheostomy had met these expectations. Since the 1970s external and endolaryngeal surgical approaches has been introduced. Recently the external laryngotracheal reconstrution (LTR) with tracheostomy is kept to be the most effective procedure, which requires a long-term tracheotomy or intubation (49). Endoscopic procedures are thought to play only a secondary role in the management, because vocal folds have a tendency for fibrosis and granulation tissue formation after surgical interventions, so a simple transsection may even worsen the condition.

To avoid these problems endoscopic solutions were introduced $(56,57,58)$. These techniques combine scar transsection with stent application or the use of antiproliferative agents to reduce scar formation between the vocal folds (18). 


\subsection{Patients}

In the past 5 years 3 children were diagnosed with laryngeal web (2 girls and 1 boy; 2, 4 and 5 years old). One of them (2-year-old boy) was already trachetomised, two girls had exertional inspiratory stridor. Two of the webs were acquired, these girls had been operated because of pediatric laryngeal papillomatosis. The third case was congenital.

\subsection{Surgical technique}

After the confirmation of the laryngeal status by direct laryngoscopy we planned minimally invasive endoscopic surgeries because none of the parents allow external intervention. The glottic area was exposed with a Kleinsasser (D) laryngoscope, and we performed CO2 -laser scar transsection (Lasram Opal-25, $5 \mathrm{~W}$ continuus-mode). Then a cotton swab soaked with Mitomycin-C (1mg/ml for 5 minutes) was applied to the anterior commissure (Fig. 12).

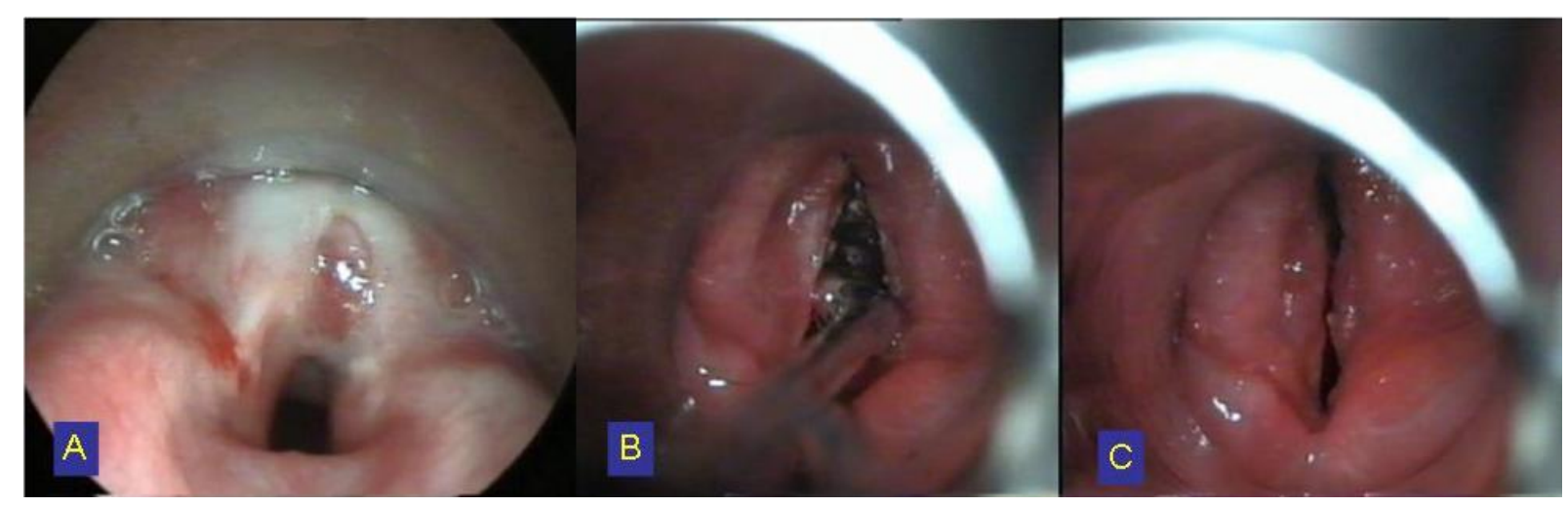

Fig. 12.: Endoscopic treatment of a laryngeal web (2 year-old boy)

A: Massive fibrous tissue between the vocal folds,

$B$ : Laryngeal web with significant subglottic extension, $\mathrm{CO}_{2}$-laser transsection

C: After laser transsection, the free, liberated vocal folds

Finally to keep the wound surfaces away of each other a $25 \mathrm{~mm}$ x $10 \mathrm{~mm}$ double-folded silicon sheet combined with a silicon tube (a $25 \mathrm{~mm}$ piece of venous catheter) was fixed by Prolene 0.0 thread into the anterior commissure (Fig. 13). 


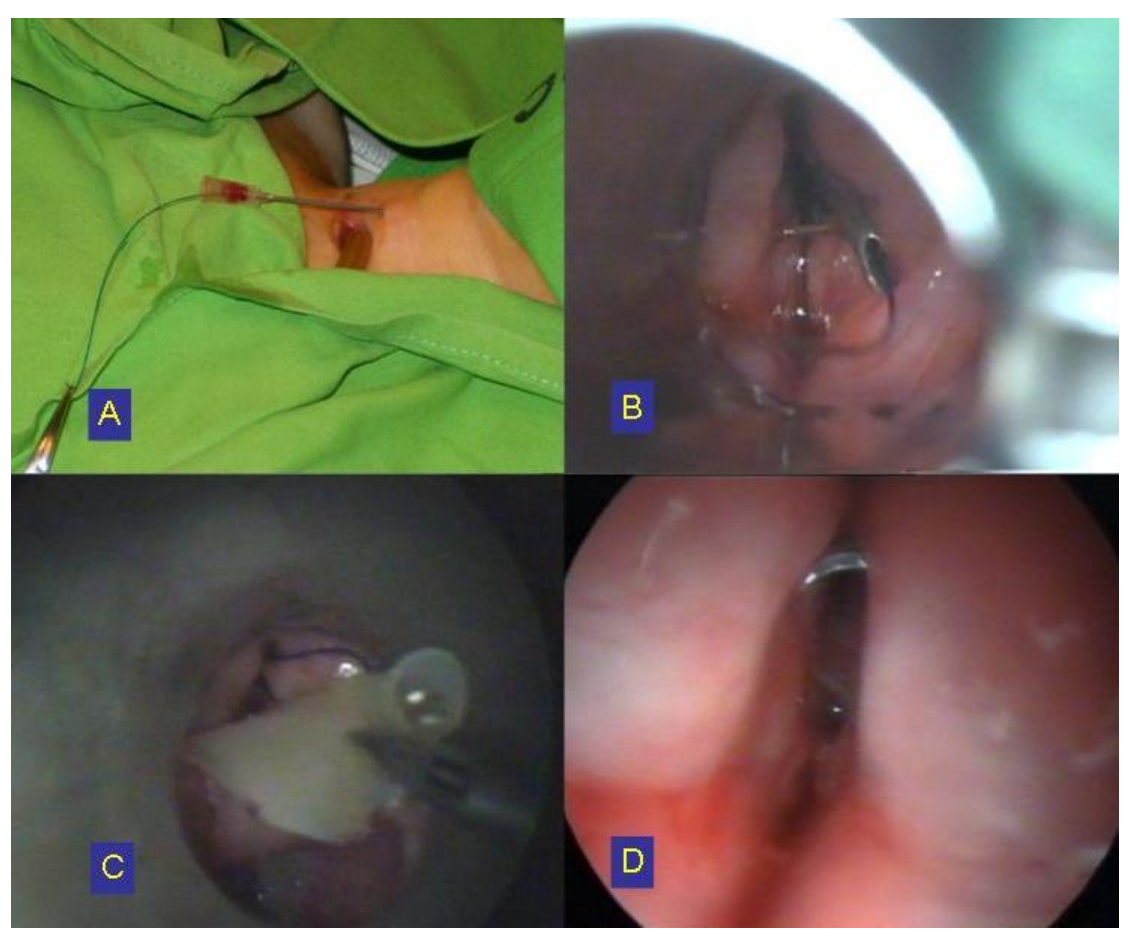

Fig. 13:Introduction and fixation of a silicon stent ( 2 year-old boy) (intraoperative photos)

$A$ and $B$ : The distal fixation thread of the stent is pulled out through a subglottic trocar.

C: Introduction of the silicon stent D: Silicon stent fixed between the vocal folds

In the first case we used Ejnell's extra-endolaryngeal suture technique (Fig. 14) for the insertion $(35,47)$. In the midline trocars (Serum 1 needle) were punctured into the lumen of the larynx at the level of the superior and inferior end of the wound, then assistant-threads were inserted into the lumen through these trocars. These assistant-threads were pulled out of the mouth, the ends of the fixation-Prolene thread of the stent were knotted to them. Then this could be fixed into the anterior commissure after pulling back the assistant-threads through the trocars (15).

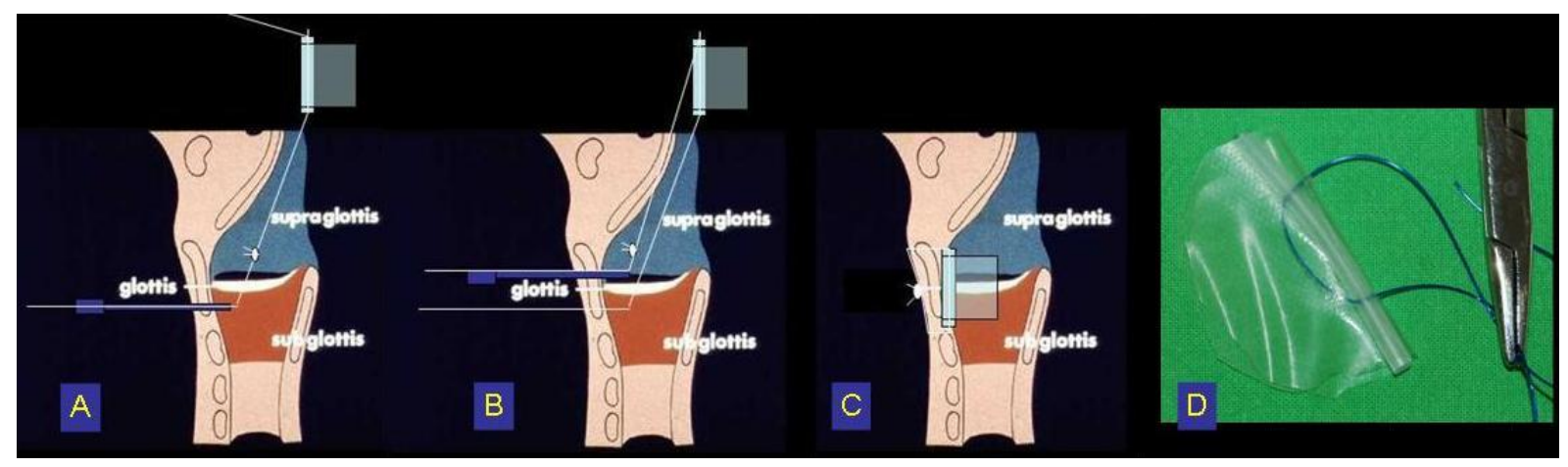

Fig. 14.: Stent fixation by extra-endolaryngeal suture technique according to Ejnell

A: The lower end of the thread securing the stent is pulled out through a subglottic trocar (thick needle).

$B$ : The upper fixation thread is pulled out through a supraglottic inserted trocar

C: The fixation threads are knotted under the skin.

D: Combined silicone tube-sheet stent 
In two cases the endolaryngeal thread guide instrument (ETGI) was used for the stent fixation (Fig. 15).

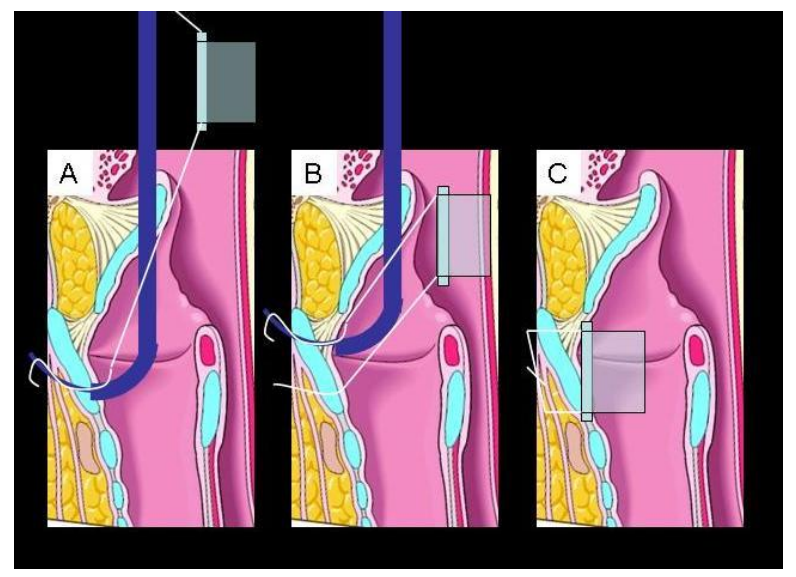

Fig. 15.: Stent fixation by ETGI (Fig. 11)

Explanation see in text

First, the inferior fixation thread was laced through the hole at the tip of the blade of ETGI, and the blade was pushed through at the inferior end of the wound in the midline out to the surface of the neck (Fig. 15A), then the thread was pulled out of the blade. The same maneuver was performed at the superior end (Fig. 15B). ETGI proved to be an effective tool for proper fixation of the stent into the anterior commissure. Compared to other endoscopic methods the fixation can be made directly through the thyroid cartilage in a proper position. This method provides a more simple intervention but requires this special instrument.

Finally the two fixation threads were pulled back from a small skin incision to the level of the sternohyoid muscle and knotted under the skin (Fig. 15C). The skin was sutured.

\subsubsection{Pediatric airway surgery for laryngo-tracheal stenoses}

In case of crico-tracheal and tracheal stenoses conservative treatment and endoscopic solutions may only be effective in case of the mildest, Grade I. stenoses $(59,60)$. According to the literature laryngo-tracheal reconstruction (LTR) (61) is the most accepted method for Grade I, II and III. Severe, Grade III and IV cases require partial cricotracheal resection (PCTR) $(61,62,63)$. In childhood the anatomical properties, the lower size of the airways made these operation really difficult and demanding for the patients. In our Clinic tracheal segment resection has been routinely applied in adults since $1989(64,65)$.

According to our experiences this surgical concept proved to be a really effective, quick method that may replace other time consuming techniques reguiring long-lasting stenting. 
For the preoperative assessment of the extent and length of the stenosis endoscopic examination is necessary. Total intravenous anaesthesia makes it possible to evaluate the airways in normal breathing without intubation and relaxation (IX). Then low frequency JETventilation $(64,65,66)$ or the classic intubational ventilation is applied during the operation.

For the resection and the anasthomosis transstomal or translaryngeal JET-ventilation is used. The skin-platysma flap is elevated after Kocher's incision. The prelaryngeal muscles are devided sagitally at the linea alba. The larynx and the trachea is released from their scarry surroundings between the levels of the middle third of the thyroid cartilage and the mediastinum (Fig. 16A).

According to the extent and severity of stenosis the following three methods are performed: 1. tracheal resection; 2. partial crico-tracheal resection; 3. Combined one-stage laryngotracheal reconstruction with crico-tracheal resection

\subsection{Tracheal resection}

Unless intraoperative direct laryngoscopy proved the laryngeal involvement tracheal resection and tracheo-tracheopexy could be done.

To avoid iatrogenic damage of the trachea the horizontal incision is done in the stenotic trachea about $1 \mathrm{~cm}$ distally from the superior end of the stenosis evaluated by preoperative endoscopy (IX). The real extension of the stenosis is assessed by distal and proximal horizontal incisions until finding totally wide airway covered by normal mucosa (Fig. 16B). The stenotic part is resected carefully to avoid the injury of the great vessels and the recurrent nerve; the the incision is made straight in the trecheal perichondrium, then the resected part can be devided from the wall of the oeseophagus (Fig. 16C) The distal tracheal end is configured fittingly to the superior end (Fig. 16D).

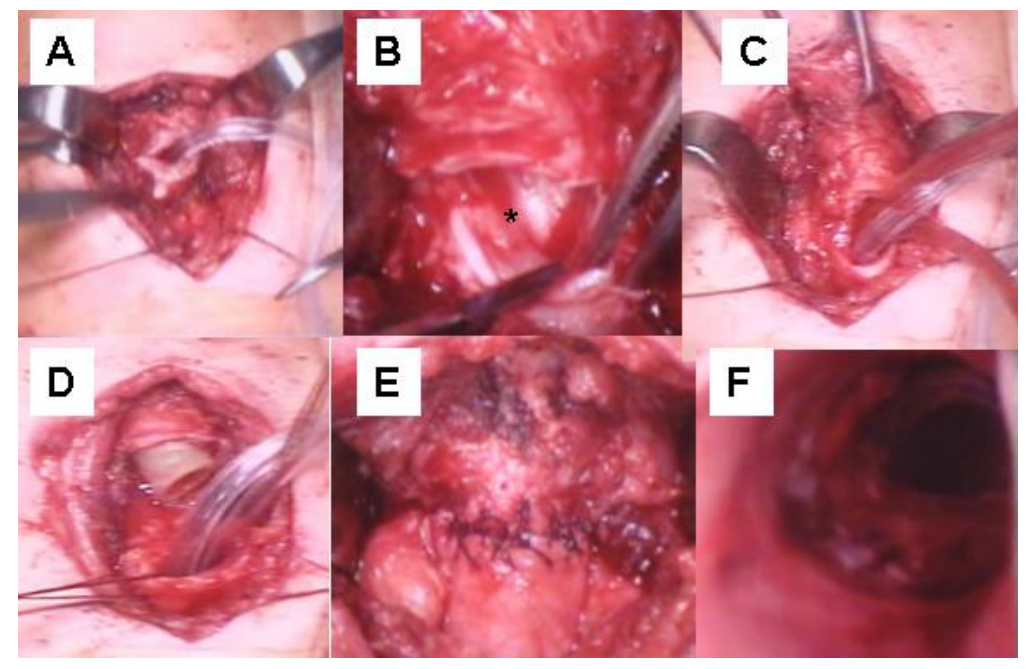

Fig. 16.: Intraoperative pictures of a 11year-old girl with tracheal stenosis A: The trachea, a JET-catheter is inserted into the former tracheostoma;

$\boldsymbol{B}$ : The proximal horizontal incision. The $100 \%$ obstructed tracheal lumen is labelled (*);

C: The distal end of the stenosis. The trachea is broad enough at the 6th tracheal ring;

D: A 3 -cm-long stenotic part is resected. Both proximal and distal ends are broad. (In the proximal end the Rüsch-tube can be seen);

$\boldsymbol{E}$ : Tracheo-tracheopexy, the anterior tracheal wall with the special suture;

$\boldsymbol{F}$ : Endoscopic intraoperative picture: a wide, stabil airway is shown after the removal of the Rüsch-tube. 
A tensionless anasthomosis creation is the key point, so the distal tracheal part has to be mobilised by blunt preparation downwards to brachiocephalical artery. The proximal and distal tracheal ends are „end-to-end” reunited by a special double continuous, uninterroupted suture (Vicryl 2/0) started at the left side of the pars membranacea (Fig. 16E). After the suture in the posterior wall transglottic intubation with Rüsch-tube is performed. If the patient had not been tracheostomed preoperatively a jet tube was used as a guide wire (12). Then the same suture technique is used in the anterior tracheal wall.

After the reunification of the soft tissue layers a surgical drain is inserted and kept in place for 3-4 days. During the first postoperative week a intravenous antibiotic treatment (cefuroxim $100 \mathrm{mg} / \mathrm{kg}$ ) haveto be applied in all cases. During the healing process the appropriate forward-bending position of the head is really important in order to decrease the tension of the anasthomosis, but no external fixation (chin-chest fixation suture or plaster cast) is necessary.

\subsection{Partial crico-tracheal resection}

In case of crico-tracheal stenosis the anterior arch of the cricoid with the stenosis have to be removed. As reconstruction an end-to-end anasthomosis of the first normal tracheal ring with the cricoid plate posteriorly and the inferior border of the thyroid cartilage anteriorly is made. If the stenosis spreaded anteriorly straight up to the level of the glottis, according to Monnier's concept a partial inferior midline thyreotomy up to the level of the anterior commissure (without transsectting it) is performed $(62,82)$. The inferior border of the thyroid cartilage may be spreaded apart. This enlarges the subglottic lumen while keeping the anterior commissure intact.

\subsection{Combined one-stage laryngo-tracheal reconstruction with crico-tracheal resection}

In case of high subglottic or glottic extension of the stenosis or extremely small newborn airway the following technique could be performed (Fig. 17). After proper mobilization and segmentresection of the stenosic tracheal part the stenotic and/or narrow cricoid and thyroid cartilages median thyreotomy and for the shake of the flexibility a complete or partial median laminotomy is done (Fig. 17A). This generally allowes the proper augmentation of the posterior subglottic stenotic part of the larynx (Fig. 17B). In the next 
step, the properly mobilised lower tracheal trunk may be pulled up, tailored and sutured to the upper trunk prepared the above mentioned way (Fig. 17C). This allows huge augmentation of the narrow subglottic area without the application of any other autogenous or alloplastic material. This makes possible the airway improvement even in very small airways, especially in newborns. 4.0-3.0 PDS suture is used for the reconstruction.

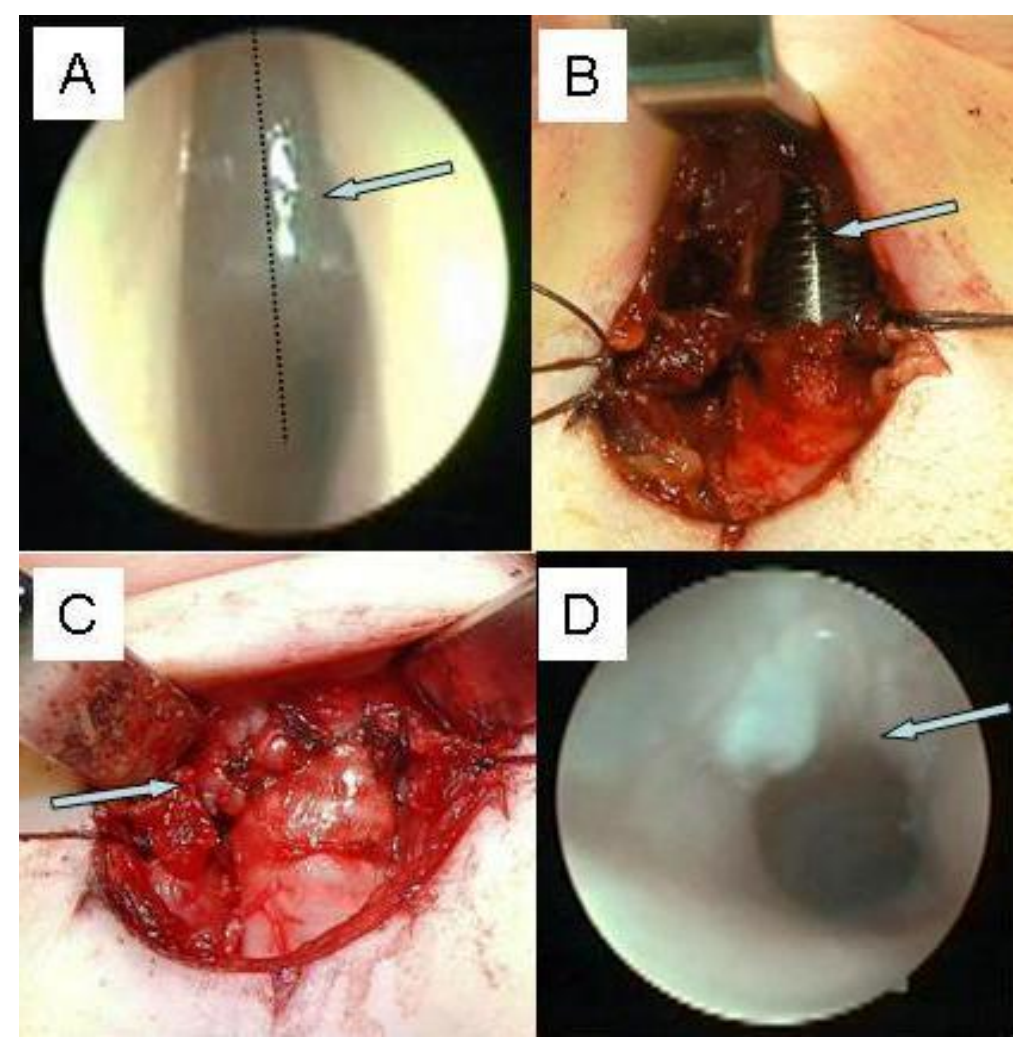

Fig. 17.: A 9-day-old boy with cricoid hypoplasia

A: Preoperative endoscopy: extended subglotto-tracheal stenosis (arrow), line shows the place of thyreotomy

B: After the resection of the stenosis; thyreotomy is done (arrow), the anterior part of the cricoid is missing, the distal end is broad enough

C: Combined one-stage laryngotracheal reconstruction with crico-tracheal resection. arrow shows the special suture.

D: Postoperative endoscopy: arrows show the anasthomosis

\subsection{Patients}

Between 1989 and 2011 fourteen children were operated, 11 boys and 3 girls. The mean age was 4,7 years ( 6 days -17 years). In 7/14 children the stenosis accured as the consequence of the intensive care performed because of car accident, burn and explosion injury, HeineMedin disease or cardiomyopathy. 6 children required long-term, 3-18-day-long intubation (mean 7 days). A child with Heine-Medin disease had an asymptomatic vascular ring causing a $4 \mathrm{~cm}$-long tracheal stenosis, who had been intubated four times before surgery. We had 2/14 'tracheostomy injuries': in an infant severe tracheal stenosis occured after tracheostomy; in a 17-year-old boy percutan tracheostomy led to crico-tracheal stenosis. In 4/14 cases (age: 9 days, 13 days, 8 months and 2 years) congenital cricoid hypoplasia was revealed, 2/14 cases 
the newborns were immediately intubated after birth because of severe stridor. In 1/14 case the origin of the stenosis was unknown.

The severity of the stenoses were evaluated according to the Cotton-Myers grading (7): we had 1 Gr.II, 8 Gr.III and 5 Gr, IV patients. In 3/14 cases only tracheal stenosis was found. After the resection of the stenotic part (in 2 cases 5 tracheal rings, in 1 case 6 tracheal rings), tracheo-trecheopexy was performed. In the majority of our cases (11/14) the cricoid and the subglottis were involved as well, so crico-tracheopexy and thyreo-crico-tracheopexy (7 cases) were done.

The Lausanne Quality of Life Questinnaire was used for the assessment of the clinical results.

\subsection{A COMPLEX EVALUATION PANEL FOR LARYNGO-TRACHEAL STENOSES - REVISION SURGERY}

Sometimes primer glottis enlarging surgery could not provide satisfactory results, the patients might be decannulated, but their quality of life is inadequate. For them a secondary, revision operation should be planned. It is questionable which glottis widening method may provide the best results in these severe, complicated cases.

In our department the endoscopic arytenoid lateropexy (EAL) was introduced for both primary and secondary treatment of BVCI (X).

Postoperative Spirometric, phoniatric tests and subjective 'Quality of Life' questionnaire were used to make results of different approaches comparable. In the past years 27 revision surgeries were performed, the 'QoL' of these patients were measured. These patients give good opportunity to demonstrate a simple, complex airway assessment panel to compare different glottis enlarging surgeries. 


\section{RESULTS}

\subsection{SURGICAL ANATOMICAL MORPHOMETRIC STUDIES}

\subsubsection{Comparison of endoscopic glottis enlarging techniques}

All analysed suture-glottis widening techniques provided significantly larger posterior glottic area compared to cadaver position (Table 1,2).

\begin{tabular}{|c|c|c|c|c|}
\hline & $\begin{array}{c}\text { Mean } \\
(\mathbf{m m})\end{array}$ & $\begin{array}{c}\text { SD } \\
+/-\end{array}$ & $\begin{array}{c}\text { Min. } \\
(\mathbf{m m})\end{array}$ & $\begin{array}{c}\text { Max. } \\
(\mathbf{m m})\end{array}$ \\
\hline $\mathbf{C P}$ & 1,69 & 0,67 & 0,58 & 3,26 \\
\hline VCL 1 suture & 5,15 & 1,23 & 2,78 & 6,56 \\
\hline VCL 2 sutures & 5,32 & 0,99 & 2,75 & 6,63 \\
\hline S & 6,04 & 1,39 & 3,19 & 9,35 \\
\hline EAL & 7,22 & 1,45 & 3,15 & 11,11 \\
\hline & & & & \\
\hline TC & 1,83 & 0,66 & 0,66 & 3,26 \\
\hline $\mathbf{A}$ & 6,63 & 1,91 & 4,14 & 8,66 \\
\hline
\end{tabular}

Table 1: The midline - vocal process distance after left-side manipulation

CP: cadaver position, VCL: vocal cord laterofixation, S: Schobel's method, EAL: endoscopic arytenoid lateropexy, TC: transverse chordotomy, A: aytenoidectomy

In case of VCL no difference occurred in the results of the one and two sutures method, the second loop did not provide additional space in the posterior glottis. EAL and S were proven to be significantly more effective than VCL. The best parameters were measured after EAL, but they were not significantly better than the ones after S (Table 3).

\begin{tabular}{|l|c|c|c|c|}
\hline & $\begin{array}{c}\text { Mean } \\
(\mathbf{o})\end{array}$ & $\begin{array}{c}\text { SD } \\
+/-\end{array}$ & $\begin{array}{c}\text { Min. } \\
(\mathbf{o})\end{array}$ & $\begin{array}{c}\text { Max. } \\
(\mathbf{o})\end{array}$ \\
\hline CP & 10,67 & 4,4 & 3,35 & 21,0 \\
\hline VCL 1 sut. & 30,46 & 7,45 & 15,56 & 47,63 \\
\hline VCL 2 sut. & 30,92 & 5,99 & 20,82 & 43,4 \\
\hline S & 47,22 & 11,09 & 33,86 & 79,89 \\
\hline EAL & 50,24 & 8,34 & 28,86 & 73,0 \\
\hline & & & & \\
\hline A & 10,79 & 4,59 & 5,34 & 20,8 \\
\hline TC & 11,49 & 4,35 & 4,3 & 19,5 \\
\hline & & & & \\
\hline
\end{tabular}

Table 2: The angle of the posterior commissure $(o=$ grad $)$ CP: cadaver position, VCL: vocal cord laterofixation, S: Schobel's method, EAL: endoscopic arytenoid lateropexy, TC: transverse chordotomy, A: aytenoidectomy 
In the second part of the study EAL, which proved to be the most effective suture lateralizing method, was compared to the resection surgical techniques (Table 1, 2). After TC the configuration of the posterior glottic area practically did not change. Arytenoidectomy seemed to be less effective than EAL because it caused no lateralisation of the vocal cord (Table 3).

\begin{tabular}{|c|c|c|c|c|}
\hline \multicolumn{5}{|c|}{ Midline - vocal process distance } \\
\hline & VCL 1 & $V C L 2$ & $S$ & $E A L$ \\
\hline $\mathrm{CP}$ & *** & $* *$ & $* *$ & $* *$ \\
\hline VCL 1 & & NS & NS & $*$ \\
\hline VCL 2 & NS & & NS & $*$ \\
\hline$S$ & NS & NS & & NS \\
\hline \multicolumn{5}{|c|}{ Angle in the posterior commissure } \\
\hline & VCL 1 & VCL 2 & $\mathrm{~S}$ & EAL \\
\hline $\mathrm{CP}$ & $* *$ & $* *$ & $* *$ & $* *$ \\
\hline VCL 1 & & NS & $*$ & $*$ \\
\hline VCL 2 & NS & & $*$ & $*$ \\
\hline $\mathrm{S}$ & $-*$ & $-*$ & & NS \\
\hline
\end{tabular}

Table 3. The statistical correlations of the results

(the horizontally signed method compared to the vertically written one)

CP: cadaver position, VCL: vocal cord laterofixation, S: Schobel's method, EAL: endoscopic arytenoid lateropexy

NS: not significant , *: significant, $p<0,01, * *$ : significant, $P<0,0001$

\subsection{EXPERIMENTAL MODEL FOR THE EVALUATION OF THE EFFICACY OF THE SPIROMETRIC PARAMETERS IN AIRWAY STENOSIS}

\subsubsection{Evaluation of normal spirometric parameters}

The reference values measured in healthy volunteers are shown in Table 4. Both male and female best results were found in the age-group 20-40 years. The mean male indices are about twice bigger than female ones. In every age group large standard deviation was found showing that no real reference inspiratory values might be established. So estimating the patients respiration the comparison to these reference values is questionable. The evaluation of the preoperative and postoperative results might be a better way to describe this condition. 


\begin{tabular}{|l|c|c|c|c|c|c|c|}
\hline & & PIF & FIV1 & FIVC & PEF & FEV1 & FVC \\
\hline Male & $\mathbf{0 - 2 0}$ y & 8,65 & 6,1 & 3,3 & 8,78 & 7,01 & 3,39 \\
\hline & SD & 2,11 & 1,3 & 0,38 & 1,65 & 1,35 & 0,48 \\
\hline & $\mathbf{2 0 - 4 0 ~ y ~}$ & 9,37 & 6,5 & 5,86 & 10,15 & 5,56 & 6,5 \\
\hline & SD & 1,12 & 0,86 & 1,39 & 1,76 & 1,18 & 1,4 \\
\hline & $\mathbf{4 0 - 6 0 ~ y ~}$ & 6,57 & 4,39 & 4,53 & 9,56 & 5 & 5,19 \\
\hline & SD & 1,06 & 1,58 & 1,55 & 2,38 & 0,99 & 1,35 \\
\hline & $\mathbf{6 0 -} \mathbf{y}$ & 6,01 & 3,68 & 3,65 & 8,96 & 4,2 & 3,98 \\
\hline & SD & 1,83 & 0,75 & 0,82 & 1,74 & 0,3 & 1,12 \\
\hline \hline Female & $\mathbf{0 - 2 0} \mathbf{y}$ & 3,96 & 2,73 & 3,01 & 5,26 & 3,49 & 3,93 \\
\hline & SD & 1 & 1,07 & 1,34 & 1,9 & 1,07 & 0,88 \\
\hline & $\mathbf{2 0 - 4 0 ~ y ~}$ & 5,62 & 2,68 & 3,19 & 7,69 & 5,12 & 4,37 \\
\hline & SD & 0,87 & 1 & 0,77 & 1,58 & 1,83 & 1,84 \\
\hline & $\mathbf{4 0 - 6 0 y}$ & 4,17 & 2,98 & 3,19 & 5,72 & 3,99 & 3,82 \\
\hline & SD & 1,34 & 1,94 & 0,94 & 2,53 & 1,72 & 0,99 \\
\hline & 60- y & 3,69 & 2,47 & 2,93 & 5,55 & 2,89 & 3,99 \\
\hline & SD & 0,83 & 0,52 & 0,81 & 0,75 & 0,61 & 0,66 \\
\hline
\end{tabular}

Table 4: Normal spirometric parameters $(n=96)$

\subsubsection{Factor analysis and correlation matrix}

Statistical factor analysis and correlation of the spiromatric parameters were examined, significant correlation was found (Table 5). The strongest correlation was found between PIF and FIV1 values $(0,899)$. Factor analysis reduced the examined 6 parameters into one factor, which meant, that the patients'condition could be described by the factor. The component matrix values showed that the FIV1 and PIF had the closest correlation to the factor (Table 6).

\begin{tabular}{|c|c|c|c|c|c|c|}
\hline & PIF & FIV1 & FIVC & PEF & FEV1 & FVC \\
\hline PIF & 1 & 0,899 & 0,557 & 0,814 & 0,675 & 0,477 \\
\hline FIV1 & 0,899 & 1 & 0,699 & 0,774 & 0,821 & 0,616 \\
\hline FIVC & 0,557 & 0,699 & 1 & 0,638 & 0,543 & 0,885 \\
\hline PEF & 0,814 & 0,774 & 0,638 & 1 & 0,716 & 0,641 \\
\hline FEV1 & 0,675 & 0,821 & 0,543 & 0,716 & 1 & 0,619 \\
\hline FVC & 0,477 & 0,616 & 0,885 & 0,641 & 0,619 & 1 \\
\hline
\end{tabular}

Table 5: Correlation of the spirometric parameters

\begin{tabular}{|c|c|c|c|c|c|c|}
\hline COMPONENT & PIF & FIV1 & FIVC & PEF & FEV1 & FVC \\
\hline 1 & $\mathbf{0 , 8 9 1}$ & $\mathbf{0 , 9 2 2}$ & $\mathbf{0 , 8 5 1}$ & $\mathbf{0 , 8 7 5}$ & $\mathbf{0 , 8 7 7}$ & $\mathbf{0 , 8 2 0}$ \\
\hline
\end{tabular}

Table 6: Factor analysis 
4.2.2. Evaluation of the deviation of pirometric parameters in different grades of stenosis

Table 7 and Fig. 19 shows the results of the 'arteficial stenosis' study. The examined indices did not change too much if $25 \%$ or $50 \%$ airway stenosis was applied. In some cases the results were even better than the references, which might be caused by a technical problem. The persons were examined several times during this procedure and they had learnt to perform perfect measurements. But the $75 \%$ stenosis significantly decreased the values. PIF and PEF were found to be the most sensitive, their values decreased about $50 \%$.

\begin{tabular}{|l|c|c|c|c|c|c|c|}
\hline & & PIF & FIV1 & FIVC & PEF & FEV1 & FEVC \\
\hline Refence values & & 6,44 & 3,95 & 3,9 & 7,89 & 4,95 & 4,59 \\
\hline & SD & 2,17 & 1,74 & 1,4 & 2,45 & 1,47 & 1,63 \\
\hline $\mathbf{2 5 \%}$ stenosis & & 6,17 & 3,81 & 3,64 & 7,48 & 4,79 & 4,07 \\
\hline & SD & 2,16 & 1,79 & 1,12 & 2,17 & 1,02 & 1,12 \\
\hline & $\begin{array}{c}\text { sten/ref } \\
\text { (\%) }\end{array}$ & 0,95 & 0,96 & 0,93 & 0,94 & 0,96 & 0,92 \\
\hline $\mathbf{5 0 \% \text { stenosis }}$ & & 5,87 & 3,98 & 4,04 & 6,94 & 4,33 & 4,39 \\
\hline & SD & 2,11 & 1,74 & 1,43 & 2,31 & 0,92 & 1,32 \\
\hline & $\begin{array}{c}\text { sten/ref } \\
\text { (\%) }\end{array}$ & 0,91 & 1,01 & 1,03 & 0,87 & 0,87 & 0,95 \\
\hline $\mathbf{7 5 \% \text { stenosis }}$ & & 3,42 & 2,71 & 3,36 & 3,9 & 3,55 & 3,8 \\
\hline & SD & 1,03 & 0,95 & 1,52 & 1,15 & 0,9 & 1,73 \\
\hline & $\begin{array}{c}\text { sten/ref } \\
\text { (\%) }\end{array}$ & 0,53 & 0,68 & 0,86 & 0,49 & 0,71 & 0,82 \\
\hline
\end{tabular}

Table 7 and Fig. 19: Deviation of spirometric parameters in different grades of stenosis (n=20)

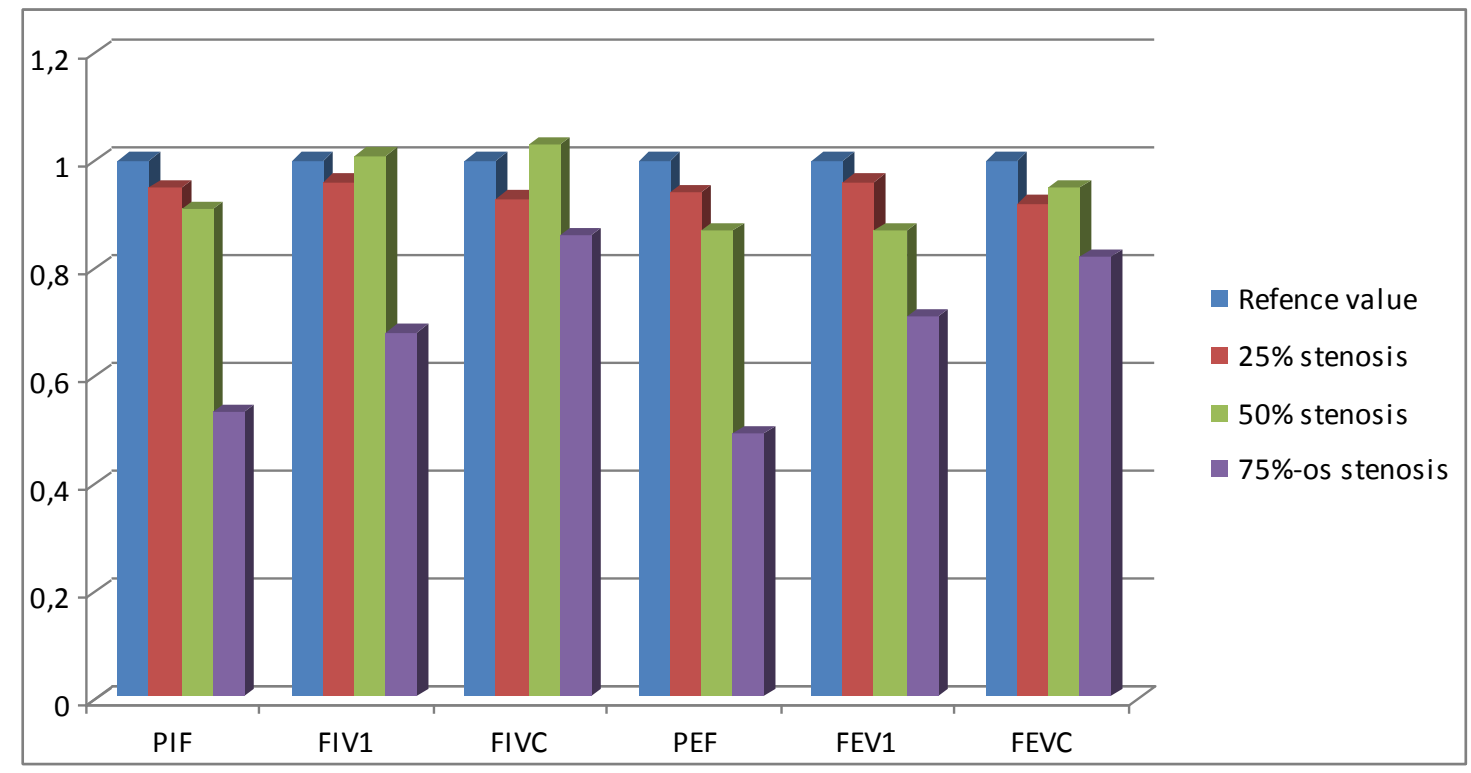




\begin{tabular}{|c|c|c|c|c|c|c|}
\hline & PIF & FIV1 & FIVC & PEF & FEV1 & FEVC \\
\hline $\mathbf{2 5 \%}$ & 0,70 & 0,88 & 0,52 & 0,58 & 0,81 & 0,26 \\
\hline $\mathbf{5 0 \%}$ & 0,39 & 0,97 & 0,75 & 0,2 & 0,20 & 0,66 \\
\hline $\mathbf{7 5 \%}$ & $1,08 \mathrm{E}-06$ & 0,05 & 0,23 & $4,4 \mathrm{E}-08$ & 0,07 & 0,13 \\
\hline
\end{tabular}

Table 8: Statistical correlations of the deviation of spirometric parameters $p<0,05$ (grey), $p<0,01$ (dark grey)

\subsection{RESULTS OF OUR ENDOSCOPIC METHOD DESIGNED FOR THE TREATMENT OF PGS}

In the first group (Bogdassarian-Olson Gr. I-III) breathing immediately and considerably improved after surgery, as also demonstrated by the breathing function test results (Table 9, Group A). PIF more than doubled and we registered further increases after one year, which may be explained by the improvement in the patients' general overall health. The patient that had worn a cannula before surgery was decannulated on the first postoperative day.

\begin{tabular}{|c|c|c|c|c|}
\hline \multicolumn{5}{|c|}{ Group A $(n=19 ;$ female/male=9/10 $)$} \\
\hline & \multirow{2}{*}{ Age (years) } & \multicolumn{3}{|l|}{ PIF (1/s) } \\
\hline & & Preop.* & Postop. & $12^{\text {th }}$ month \\
\hline Mean & 38,68 & 1,21 & 2,42 & 3,08 \\
\hline Min./max. & $15 / 74$ & $(0,55 / 2,22)$ & $(1,62 / 3,8)$ & $(1,55 / 4)$ \\
\hline SD & 15,52 & $\pm 0,63$ & $\pm 0,77$ & $\pm 0,61$ \\
\hline \multicolumn{5}{|c|}{ Group B $(n=23 ;$ female $/$ male $=7 / 16)$} \\
\hline & \multirow{2}{*}{ Age (years) } & \multicolumn{3}{|l|}{ PIF (1/s) } \\
\hline & & Preop.* & Postop. & $12^{\text {th }}$ month \\
\hline Mean & 51,63 & 1.41 & 2,74 & 2,67 \\
\hline Min./max. & $17 / 65$ & $(0,5 / 2,0)$ & $(1,7 / 4,62)$ & $(1,45 / 4,75)$ \\
\hline SD & 14,73 & $\pm 0,51$ & $\pm 0,73$ & $\pm 0,88$ \\
\hline
\end{tabular}

Table 9: Spirometric results

Group A: B-O Gr. I-III.

Group B: B-O Gr. IV. 
The lateralizing sutures ensured a stable abducted position at rest, but during forced phonation or coughing some adduction of the vocal cords was detected. The fixating sutures were removed in 17 cases after reepithelization of the surgical site. Once this was done, phonation became easier and only a minimal closure gap between the vocal processes could be observed during phonation. The voice achieved was usually a bit hoarse, and a slightly breathy voice, although similar in quality to their original voice. In the 2 cases caused by failed arytenoidectomy the lateralizing sutures were not removed.

In the group of severe stenosis (Table 9, Group B), preoperative breathing function tests could only be performed in 11 cases due to the tracheostomy cannula worn by 6 patients for severe dyspnea. Hence, the true preoperative average is probably somewhat lower than the one indicated in the table. With this in mind, the approximately doubled breathing ability of this group, based on the PIF values measured after surgery, is in truth higher; the improvement of PIF in Group B may actually be closer to the PIF increase measured in the first group. Also, the PIF values of this group (Group B) are somewhat higher than those measured in the first group (Group A), but we should consider that there were more women in Group A than in Group B. Five of the 6 patients with a cannula could be decannulated. Although the glottic size of 3-4 mm would have allowed it, the tracheostomy could still not be abolished in the patient with post-irradiation stenosis, due to the extent of post-irradiation edema in the supraglottis and the aspiration of liquids. The average PIF shows a slight decrease at the end of the first year (Table 9), but considerable restenosis occured in only three patients. Even in these cases breathing was adequate at rest, with stridor presenting only upon effort.

We removed the lateralizing sutures in 12 cases. This was followed by a considerable improvement in vocal cord mobility and voice quality in 9 patients, and only in 3 patients did the voice remain hoarse and breathy. From the remaining 5 cases a good false vocal cord phonation with socially acceptable voice developed in 3 patients. Voice remained whispering only in the two cases with previous unsuccessful bilateral arytenoidectomy.

Postoperative aspiration, which presented mostly in cases of fluid intake, markedly diminished in 2-7 days as proven by radiological examinations, and completely disappeared in 29 patients in a few weeks. A slight degree of aspiration persisted in 2 cases, beside the patient whom we could not decannulate. There have been no serious complications (e.g. recurring pneumonia) so far. 
In summary twenty eight of the 32 patients achieved an improved breathing ability that allowed them to return to their previous way of life. Only effort dyspnea remained in 3 cases. One patient could not be decannulated due to aspiration. In 22 of 25 cases, adduction and phonation significantly improved after the removal of the fixing sutures.

\subsection{A SUBJECTIVE QUALITY OF LIFE QUESTIONNAIRE FOR THE EVALUATION OF PEDIATRIC STENOSES}

\subsubsection{Endoscopic complex management of laryngeal web}

The silicone stent was removed from the anterior commissure 3-5 weeks after surgery. The adequacy of the glottis let us to decannulate the tracheostomised patient. His tracheostoma closed spontaneously.

The patients' voice became hoarse and strained with a higher pitch but undertandable and socially acceptable.

The Lausanne Quality Of Life Questionnaire showed improvement of the breathing, the voice and overall satisfaction (Table 10).

\begin{tabular}{|c|c|c|c|c|c|c|}
\hline & $\begin{array}{c}\text { Breathing } \\
(1-5)\end{array}$ & $\begin{array}{c}\text { Noise } \\
(1-5)\end{array}$ & $\begin{array}{c}\text { Coughing } \\
(1-4)\end{array}$ & $\begin{array}{c}\text { Voice } \\
(1-4)\end{array}$ & $\begin{array}{c}\text { Deglution } \\
(1-3)\end{array}$ & $\begin{array}{c}\text { Satisfaction } \\
(1-4)\end{array}$ \\
\hline Preoperative & $\mathbf{3 , 6 6}$ & $\mathbf{3 , 0 0}$ & $\mathbf{1 , 0 0}$ & $\mathbf{3 , 0 0}$ & $\mathbf{1 , 0 0}$ & $\mathbf{3 , 6 6}$ \\
\hline SD & 1,15 & 1,73 & 0 & 1,00 & 0 & 0,57 \\
\hline Postoperative & $\mathbf{1 , 6 6}$ & $\mathbf{1 , 3 3}$ & $\mathbf{1 , 0 0}$ & $\mathbf{2 , 0 0}$ & $\mathbf{1 , 0 0}$ & $\mathbf{1 , 3 3}$ \\
\hline SD & 0,57 & 0,57 & 0 & 0 & 0 & 0,57 \\
\hline
\end{tabular}

Table 10: Quality of Life - laryngeal web (n=3)

\subsubsection{Pediatric airway surgery for laryngo-tracheal stenoses}

In case of older children the intubation tube was removed straight after the surgery, but in case of six younger children 2-3 days of postoperative intubation was necessary in the pediatric intensive care unit. One child was suffering from grand mal epileptic seizures caused by severe congenital central nervous system lesion, he had to be intubated for a longer period of time. In case of ten out of the other twelve chindren the stenosis could be solved. In one 
boy who had suffered severe airway burn injury, $30 \%$ restenosis occured which had no effect on his breathing.

QoL Questionnaires showed significant improvement of breathing and overall satisfaction, while the voice quality slightly decreased (Table 11)

\begin{tabular}{|c|c|c|c|c|c|c|}
\hline & $\begin{array}{c}\text { Breathing } \\
(1-5)\end{array}$ & $\begin{array}{c}\text { Noise } \\
(1-5)\end{array}$ & $\begin{array}{c}\text { Coughing } \\
(1-4)\end{array}$ & $\begin{array}{c}\text { Voice } \\
(1-4)\end{array}$ & $\begin{array}{c}\text { Deglution } \\
(1-3)\end{array}$ & $\begin{array}{c}\text { Satisfaction } \\
(1-4)\end{array}$ \\
\hline Preoperative & $\mathbf{3 , 7 8}$ & $\mathbf{3 , 6 4}$ & $\mathbf{1 , 4 3}$ & $\mathbf{2 , 5}$ & $\mathbf{1 , 2 1}$ & $\mathbf{3 , 7 8}$ \\
\hline SD & 0,97 & 1,08 & 0,64 & 0,94 & 0,42 & 0,42 \\
\hline Postoperative & $\mathbf{1 , 7 1}$ & $\mathbf{1 , 5 0}$ & $\mathbf{1 , 2 1}$ & $\mathbf{2 , 0 0}$ & $\mathbf{1 , 1 5}$ & $\mathbf{1 , 5 7}$ \\
\hline SD & 0,61 & 0,65 & 0,43 & 0,67 & 0,36 & 0,64 \\
\hline $\begin{array}{c}\text { Statistical } \\
\text { correlation }\end{array}$ & $\mathbf{3 , 7 9 E - 7}$ & $\mathbf{9 , 9 9 E - 7}$ & $\mathbf{0 , 3 1}$ & $\mathbf{0 , 1 1}$ & $\mathbf{0 , 6 3}$ & $\mathbf{5 , 0 2 E - 1 1}$ \\
\hline
\end{tabular}

Table 11: Quality of Life - pediatric laryngo-tracheal stenosis $(n=14), p<0,001$

Table 12 shows the results of our all pediatric cases (laryngeal web and laryngo-tracheal stenosis).

\begin{tabular}{|c|c|c|c|c|c|c|}
\hline & $\begin{array}{c}\text { Breathing } \\
(1-5)\end{array}$ & $\begin{array}{c}\text { Noise } \\
(1-5)\end{array}$ & $\begin{array}{c}\text { Coughing } \\
(1-4)\end{array}$ & $\begin{array}{c}\text { Voice } \\
(1-4)\end{array}$ & $\begin{array}{c}\text { Deglution } \\
(1-3)\end{array}$ & $\begin{array}{c}\text { Satisfaction } \\
(1-4)\end{array}$ \\
\hline Preoperative & $\mathbf{3 , 7 6}$ & $\mathbf{3 , 5 2}$ & $\mathbf{1 , 3 5}$ & $\mathbf{2 , 5 9}$ & $\mathbf{1 , 1 7}$ & $\mathbf{3 , 7 6}$ \\
\hline SD & 0,97 & 1,17 & 0,60 & 0,93 & 0,39 & 0,43 \\
\hline Postoperative & $\mathbf{1 , 7 0}$ & $\mathbf{1 , 4 7}$ & $\mathbf{1 , 1 7}$ & $\mathbf{2 , 0 0}$ & $\mathbf{1 , 1 2}$ & $\mathbf{1 , 5 3}$ \\
\hline SD & 0,58 & 0,62 & 0,39 & 0,62 & 0,33 & 0,62 \\
\hline $\begin{array}{c}\text { Statistical } \\
\text { correlation }\end{array}$ & $\mathbf{1 , 6 1 E - 0 8}$ & $\mathbf{3 , 8 0 E - 0 7}$ & $\mathbf{0 , 3 2}$ & $\mathbf{0 , 0 4}$ & $\mathbf{0 , 6 4}$ & $\mathbf{1 , 7 9 E - 1 3}$ \\
\hline
\end{tabular}

Table 12: Quality of Life - pediatric cases (n=17), $p<0,001$

\subsection{A COMPLEX EVALUATION PANEL FOR LARYNGO-TRACHEAL STENOSES - REVISION SURGERY}

Since 1989237 patients were operated because of bilateral vocal cord immobility. The excellent experiences encouraged us to re-operate those patients who had undergone any type of glottis enlarging operations, but they were unsatisfied with the result. For them a secondary, revision surgery was performed. 
4.5.1. EAL after VCL $(n=11)$

\begin{tabular}{|c|c|c|c|c|c|c|}
\hline & $\begin{array}{c}\text { Breathing } \\
(1-5)\end{array}$ & $\begin{array}{c}\text { Noise } \\
(1-5)\end{array}$ & $\begin{array}{c}\text { Coughing } \\
(1-4)\end{array}$ & $\begin{array}{c}\text { Voice } \\
(1-4)\end{array}$ & $\begin{array}{c}\text { Deglution } \\
(1-3)\end{array}$ & $\begin{array}{c}\text { Satisfaction } \\
(1-4)\end{array}$ \\
\hline Preoperative & $\mathbf{2 , 6 3}$ & $\mathbf{2 , 2 7}$ & $\mathbf{1 , 3 8}$ & $\mathbf{2 , 8 1}$ & $\mathbf{1}$ & $\mathbf{3 , 1 8}$ \\
\hline SD & 1,07 & 1,16 & 0,70 & 0,54 & 0 & 1,08 \\
\hline Postoperative & $\mathbf{1 , 1}$ & $\mathbf{1}$ & $\mathbf{1}$ & $\mathbf{2 , 2 7}$ & $\mathbf{1}$ & $\mathbf{1 , 4 5}$ \\
\hline SD & 0,30 & 0 & 0 & 0,47 & 0 & 0,50 \\
\hline $\begin{array}{c}\text { Statistical } \\
\text { correlation }\end{array}$ & $\mathbf{0 , 0 0 0 1 1}$ & $\mathbf{0 , 0 0 0 4 3}$ & $\mathbf{0 , 0 3 9}$ & $\mathbf{0 , 4 5}$ & $\mathbf{0 , 1 3}$ & $\mathbf{0 , 0 0 0 3 9}$ \\
\hline
\end{tabular}

PIF (L/s)

VCL: $1,77 \pm 0,33$

EAL: $2,52 \pm 0,74$
Table 13: EAL as revision surgery after $\operatorname{VCL}(N=11), p<0,001$

QoL Questionnaire and spirometric results

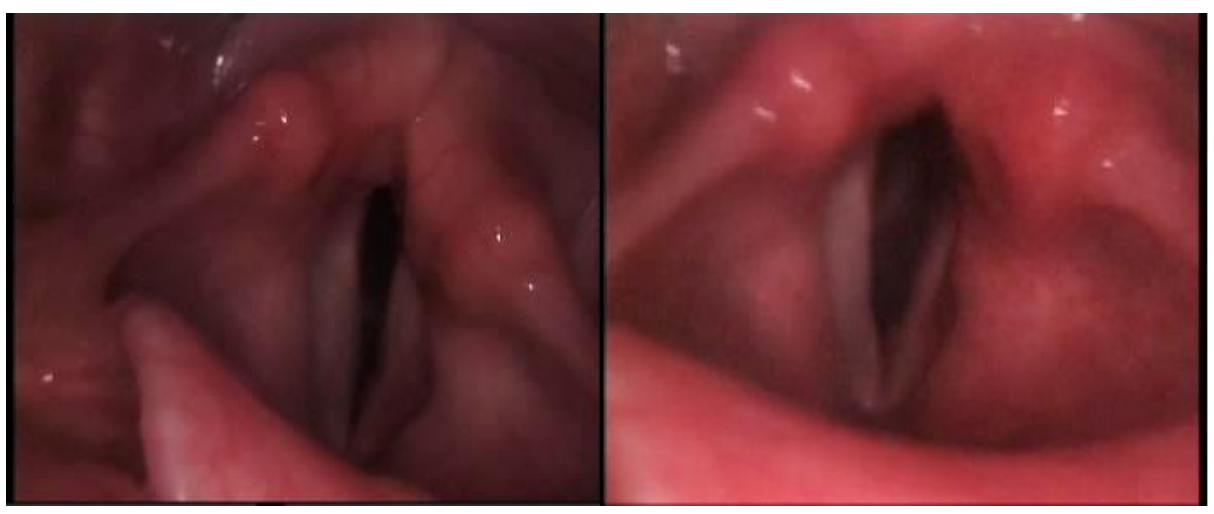

Fig.20: V.C, $45 Y$ woman

Left side VCL (left), left side EAL (right)

\subsubsection{EAL after unilateral arytenoidectomy $(n=6)$}

\begin{tabular}{|c|c|c|c|c|c|c|}
\hline & $\begin{array}{c}\text { Breathing } \\
(1-5)\end{array}$ & $\begin{array}{c}\text { Noise } \\
(1-5)\end{array}$ & $\begin{array}{c}\text { Coughing } \\
(1-4)\end{array}$ & $\begin{array}{c}\text { Voice } \\
(1-4)\end{array}$ & $\begin{array}{c}\text { Deglution } \\
(1-3)\end{array}$ & $\begin{array}{c}\text { Satisfaction } \\
(1-4)\end{array}$ \\
\hline Preoperative & $\mathbf{2 , 6 3}$ & $\mathbf{2 , 2 7}$ & $\mathbf{1 , 3 8}$ & $\mathbf{2 , 8 1}$ & $\mathbf{1}$ & $\mathbf{3 , 1 8}$ \\
\hline SD & 1,07 & 1,16 & 0,70 & 0,54 & 0 & 1,08 \\
\hline Postoperative & $\mathbf{1 , 1}$ & $\mathbf{1}$ & $\mathbf{1}$ & $\mathbf{2 , 2 7}$ & $\mathbf{1}$ & $\mathbf{1 , 4 5}$ \\
\hline SD & 0,30 & 0 & 0 & 0,47 & 0 & 0,50 \\
\hline
\end{tabular}

\section{PIF (L/s) \\ A: $\quad 2,57 \pm 1,35$ \\ EAL: $4,35 \pm 1,92$}

Table 14: EAL after unilateral arytenoidectomy $(N=6)$ QoL Questionnaire and spirometric results

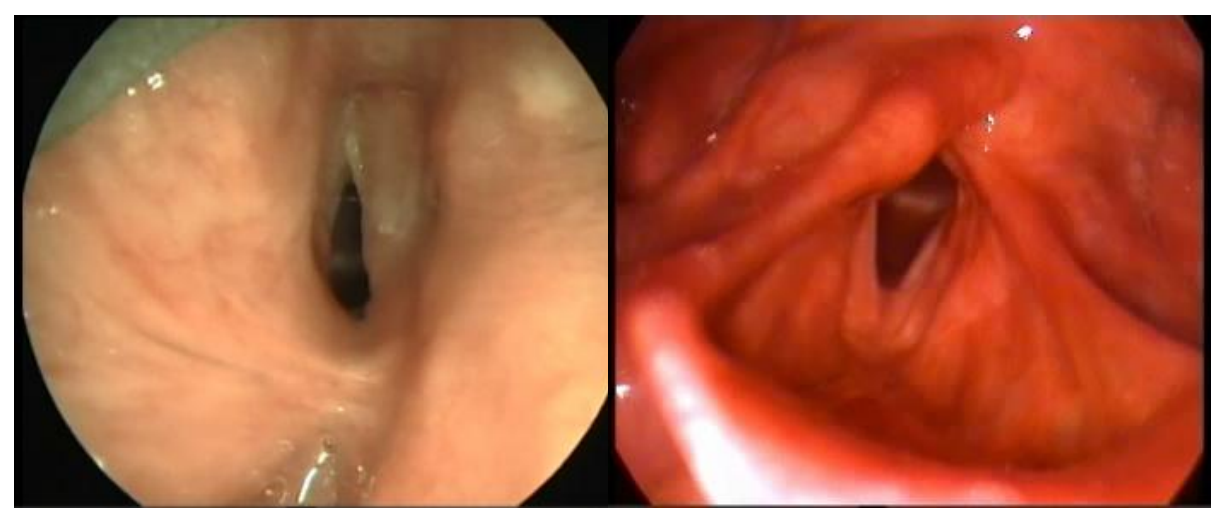

Fig. 21: V.R., $45 Y$ man, right side arytenoidectomy (left) and after EAL (right) 
4.5.3. EAL after bilateral arytenoidectomy $(n=6)$

\begin{tabular}{|c|c|c|c|c|c|c|}
\hline & $\begin{array}{c}\text { Breathing } \\
(1-5)\end{array}$ & $\begin{array}{c}\text { Noise } \\
(1-5)\end{array}$ & $\begin{array}{c}\text { Coughing } \\
(1-4)\end{array}$ & $\begin{array}{c}\text { Voice } \\
(1-4)\end{array}$ & $\begin{array}{c}\text { Deglution } \\
(1-3)\end{array}$ & $\begin{array}{c}\text { Satisfaction } \\
(1-4)\end{array}$ \\
\hline Preoperative & $\mathbf{3 , 8 3}$ & $\mathbf{3 , 5 0}$ & $\mathbf{1 , 3 3}$ & $\mathbf{2 , 1 6}$ & $\mathbf{1 , 1 6}$ & $\mathbf{3 , 5 0}$ \\
\hline SD & 0,75 & 0,84 & 0,51 & 0,94 & 0,41 & 0,55 \\
\hline Postoperative & $\mathbf{1 , 6 6}$ & $\mathbf{1 , 5 0}$ & $\mathbf{1 , 3 3}$ & $\mathbf{2 , 3 3}$ & $\mathbf{1 , 1 7}$ & $\mathbf{2 , 5 0}$ \\
\hline SD & 0,52 & 0,55 & 0,51 & 0,81 & 0,40 & 0,55 \\
\hline
\end{tabular}

Table 15: EAL after bilateral arytenoidectomy $(N=6)$

QoL Questionnaire and spirometric results

\section{PIF (L/s)}

A: $\quad 1,65 \pm 0,85$

EAL: 3,01 $\pm 1,26$

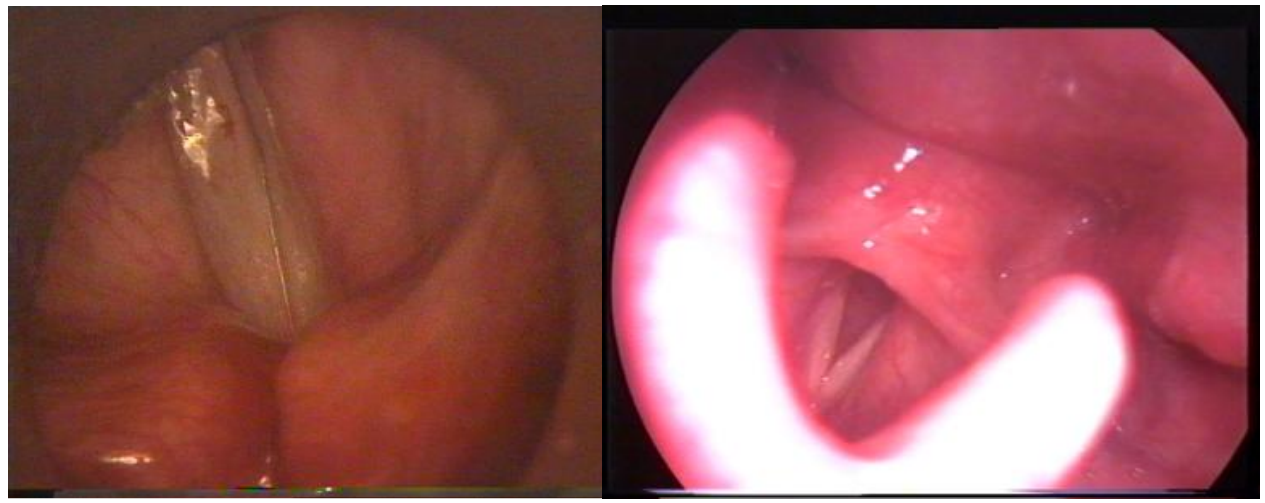

Fig. 22: S.L, 62Y man, tracheostomised for 30 years

\subsubsection{EAL after Rethi II $(\mathrm{n}=4)$}

\begin{tabular}{|c|c|c|c|c|c|c|}
\hline & $\begin{array}{c}\text { Breathing } \\
(1-5)\end{array}$ & $\begin{array}{c}\text { Noise } \\
(1-5)\end{array}$ & $\begin{array}{c}\text { Coughing } \\
(1-4)\end{array}$ & $\begin{array}{c}\text { Voice } \\
(1-4)\end{array}$ & $\begin{array}{c}\text { Deglution } \\
(1-3)\end{array}$ & $\begin{array}{c}\text { Satisfaction } \\
(1-4)\end{array}$ \\
\hline Preoperative & $\mathbf{3 , 7 5}$ & $\mathbf{3 , 7 5}$ & $\mathbf{1 , 7 5}$ & $\mathbf{2 , 5 0}$ & $\mathbf{1 , 5}$ & $\mathbf{3 , 5}$ \\
\hline SD & $\mathbf{0 , 9 6}$ & $\mathbf{0 , 9 6}$ & 0,5 & 1,30 & 1,00 & 0,58 \\
\hline Postoperative & $\mathbf{1 , 7 5}$ & $\mathbf{1 , 7 5}$ & $\mathbf{1}$ & $\mathbf{2}$ & $\mathbf{1 , 0 0}$ & $\mathbf{1 , 5 0}$ \\
\hline SD & 0,50 & 0,50 & 0 & 0,82 & 0 & 0,57 \\
\hline
\end{tabular}

Table 15: EAL after Rethi II. $(N=4)$

PIF (L/s)

R. $1,7 \pm 0,34$

EAL: $2,85 \pm 1,12$

QoL Questionnaire and spirometric results

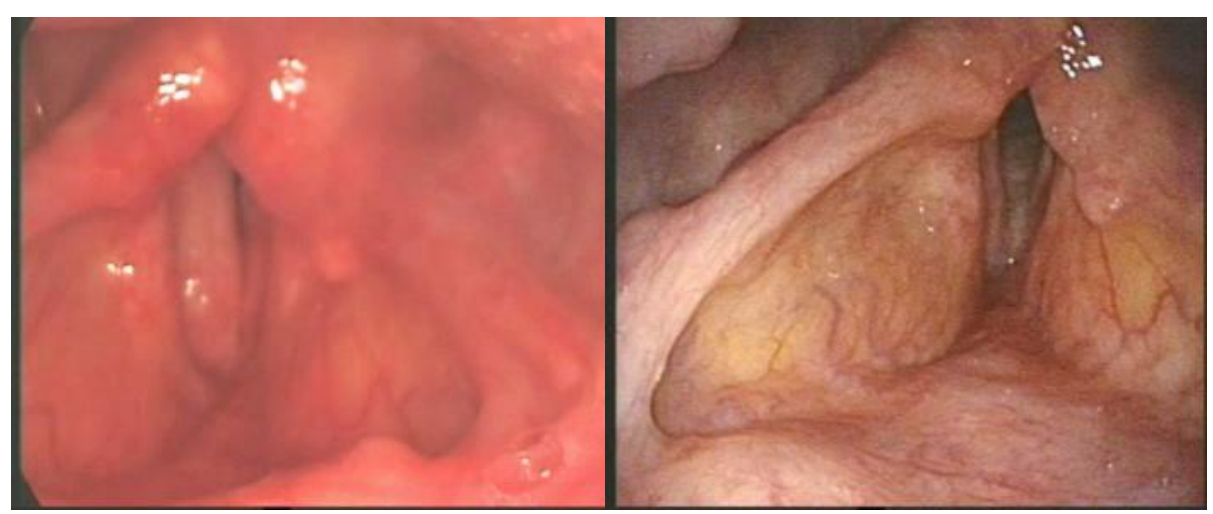

Fig. 23: CS.J., $61 Y$ man 
4.5.5. EAL as revision surgery $(n=27)$

\begin{tabular}{|c|c|c|c|c|c|c|}
\hline & $\begin{array}{c}\text { Breathing } \\
(1-5)\end{array}$ & $\begin{array}{c}\text { Noise } \\
(1-5)\end{array}$ & $\begin{array}{c}\text { Coughing } \\
(1-4)\end{array}$ & $\begin{array}{c}\text { Voice } \\
(1-4)\end{array}$ & $\begin{array}{c}\text { Deglution } \\
(1-3)\end{array}$ & $\begin{array}{c}\text { Satisfaction } \\
(1-4)\end{array}$ \\
\hline Preoperative & $\mathbf{2 , 7 9}$ & $\mathbf{2 , 6 8}$ & $\mathbf{1 , 4 3}$ & $\mathbf{2 , 3 5}$ & $\mathbf{1 , 2 6}$ & $\mathbf{2 , 8 4}$ \\
\hline SD & 1,12 & 1,22 & 0,67 & 0,66 & 0,57 & 1,07 \\
\hline Postoperative & $\mathbf{1 , 4 1}$ & $\mathbf{1 , 3 7}$ & $\mathbf{1 , 0 8}$ & $\mathbf{2 , 1 6}$ & $\mathbf{1 , 0 4}$ & $\mathbf{1 , 3 7}$ \\
\hline SD & 0,48 & 0,48 & 0 & 0,47 & 0 & 0,48 \\
\hline $\begin{array}{c}\text { Statistical } \\
\text { correlation }\end{array}$ & $\mathbf{2 , 6 4 E - 0 7}$ & $\mathbf{2 , 3 0 E - 0 6}$ & $\mathbf{0 , 0 2}$ & $\mathbf{0 , 2 5}$ & $\mathbf{0 , 0 6}$ & $\mathbf{7 , 3 0 E - 0 6}$ \\
\hline
\end{tabular}

PIF (L/s)

Table 16: EAL after failed glottis enlarging procedures. $(N=27)$

Preop: $1,89 \pm 1,01$

EAL: $3,56 \pm 1,57$ 


\section{DISCUSSION}

\subsection{SURGICAL ANATOMICAL MORPHOMETRIC STUDIES}

Morphometric studies analysing the results of different glottis widening procedures had already been published. Eckel and Sittel used shock-frozen cadaver larynges to measure the efficacy of cordotomy and arytenoidectomy. Horizontal sections were produced and crosssectional areas of the vocal cords and arytenoids were measured using a computer-aided morphometry device (67). Their method provided an objective comparison between the examined procedures, but it was expensive and time consuming which limited the extension of the study. The great anatomical variability of this organ requires adequate series of study specimens (68). Other deficiencies are that the horizontal projection of the three-dimension movements of the arytenoids might not be analysed by their method and different glottis widening methods could not be performed on the same organ.

These technical imperfections can be avoided by applying our simple digital image analysing morphometric method. The cadaver larynges are fixed in a standard position and high-resolution sharp, distortionless photos may be taken. The surgical anatomical parameters of different procedures can easily be assessed in the plane perpendicular to the median-sagittal plane of the larynges. Large number of larynges were used which allowed correct statistical comparison considering the anatomical variability. It is another advantage that reversible procedures can be analysed on the same organ.

Theoretically, a widely open posterior commissure should be maintained in order to prevent restenosis in the posterior commissure after surgery for PGS. It can obviously be achieved with the arytenoid cartilages in the position of maximal inspiration due to the anatomic properties of this region. The movement of the cricoarytenoid joint is not a simple rotation around the vertical axis, which is generally considered to be the theoretical basis for simple vocal cord laterofixation techniques, exists only in standard anatomy textbooks. (69) Wang has convincingly demonstrated that during abduction the lateral sliding motion of the vocal process is accompanied by an upward and occasionally slightly posterior movement simultaneously, with the arytenoid cartilage turning laterally and upward on the cricoid cartilage facet. $(70,71)$

Our cadaver studies proved that this abducted position of the joint can be configured by tilting the arytenoid cartilage backwards and then fixating with a suture loop. EAL based on 
these manoeuvres (VI) provide better results than other suture lateralizing methods. This fixation spares the phonation surface of the vocal cords which allows better postoperative voice than procedures involve the resection of glottic structure. In case of posterior glottic stenosis the procedure is performed bilaterally $(\mathrm{I}, 38)$, so the differences between the results of different techniques appear more markedly.

The analysis of VCL showed some improvement but the second suture loop does not provide additional area in the posterior glottis. The external arytenoid lateropexy, Schobel's method proved to be much more effective, its results are comparable to the results of minimally invasive EAL. TC provided no significant area increase in the posterior commissure compared to the initial cadaver position. TC may be effective in the treatment of dyspnea but the configuration of the damaged posterior glottic area does not change the arytenoid remains in a median position so the frequently described scar formation on the surgical site (30) may cause a more severe suffocation in the long run than in case of a bilateral vocal cord paralysis. Arytenoidectomy provided better results than VCL, but worse than EAL. This intervention does not really change the position of the rest of the vocal cord, which explains the generally only moderate breathing improvement. The scarry surgical area renders to be difficult the creation of a mucosal flap by the preservation of the medial mucosa of the arytenoid, which especially in case of a fixated contralateral arytenoid, predicts a possible significant restenosis as well. The lack of the proper fixation technique against the affect of the contraction of the developed scar tissue also means a disadvantage in case of a high grade stenosis. Another handicap of these resection methods is that the markedly removal of glottic subtance causes generally an irreversible function loss.

\subsection{EXPERIMENTAL MODEL FOR THE EVALUATION OF THE EFFICACY OF THE SPIROMETRIC PARAMETERS IN AIRWAY STENOSES}

Since the 1970s lung function tests have become an indispensable tool for the clinical evaluation of respiratory health and disease. Spirometry is widely accepted as a clinical tool for diagnosing obstructive, restrictive or mixed ventilatory defects. It plays an essential role in the diagnosis and management of respiratory diseases, especially asthma and chronic obstructive pulmonary disease (COPD) (40,41).

Spirometry may be applied also in cases of extrathoracal stenoses, such as glottic and subglotto-tracheal stenoses, in which the cross section diameter of the larynx and/or trachea is 
decreased leading to inspiratory dyspnea. Kashima (43) and Cantarella (42) proved that inspiratory flows were significantly reduced, whereas with the exception of PEF, the expiratory flows were in the normal range. Vössing found that Peak expiratory flow was the most sensitive parameter, it reacted earlier than did peak inspiratory flow and seemed to be the most reliable parameter for detecting an extrathoracic stenosis (72).

In our study normal reference inspiratory indices wanted to be measured, but in each age group all indices had a large standard deviation. Maybe, if we could have increased the number of examined persons and they could have been divided into more subgroups (e.g: overall healt condition, age, weight, etc), the smaller standard deviation in the parameters had been found. These findings showed that in a single patient it did not really worth to compare his spirometric values to normal ones. It could be more valueable to compare only the preand postoperative status.

Factor analysis of the spirometry of stenotic patients showed that FIV1 and PIF indices could describe the stenotic condition the best. In the experimental model we had the same results. In our earlier studies FIV1 was applied for the evaluation of the results but later according to the literature we used PIF as well. These results well-correlates with the physics of aerodynamic. Bernoulli's thesis describes that the quickening of the airflow through the stenotic part of a tube creates a suction on the tube wall, which may improve the stenosis and the turbulency of the airflow. This presents a resistence increasing leading to breathing deterioration in the extrathoracic part of the airway. The deviation of expiratory indices is the consequence of the decreased inspired air volume, so these are secondary changes. In the clinical practice this phenomen is well-demonstrated by the inspiratory stridor.

\subsection{ENDOSCOPIC ARYTENOID LATEROPEXY FOR POSTERIOR GLOTTIC STENOSIS}

If we want to prevent restenosis during surgery for PGS by means of maintaining a widely open posterior commissure, it can obviously be achieved with the arytenoid cartilages in the position of maximal inspiration due to the anatomic properties of this region. One basic condition of this, however, is that the scars inhibiting the cricoarytenoid joint mobility should be abolished. In simple cases this can be done by dissecting the scar between the arytenoid cartilages, but in more severe situations the scarry destruction or the traumatic arthritis of the joint necessitates further intervention. Due to the hidden location of the joint, mobilization by 
laser can only be implemented by resecting a considerable part of the arytenoid cartilage with its covering mucosa. This may lead to postoperative voice quality deterioration. Furthermore, damage to mucosal receptors may increase the risk of aspiration (51). By using our rigid, right-angled endolaryngeal scythe, the scars between the cricoid and arytenoid cartilage immobilizing the cricoarytenoid joint can be transected with minimal tissue trauma, which can then be followed by lateropexy without the above disadvantages. The effectiveness of the method is obvious, as the postoperative improvement in the PIF values were similar in both groups. In the majority of cases the transitory postoperative aspiration ceased or diminished within a few days.

Another basic condition for the successful application of the suggested method is the fixation of the arytenoid cartilages in the physiologically maximal abducted position. The simple rotation around the vertical axis, which is generally considered to be the theoretical basis for simple vocal cord laterofixation techniques, exists only in standard anatomy textbooks but is not found in investigations on the subject. A helical axis close to vertical has been suggested $(73,74)$. Wang (71) has convincingly demonstrated that during abduction the lateral sliding motion of the vocal process is accompanied by an upward and occasionally slightly posterior movement simultaneously, with the arytenoid cartilage turning laterally and upward on the cricoid cartilage facet. On full abduction the arytenoid cartilage lies laterally at the upper and outer cricoid facet, having moved superiorly, posteriorly, and laterally.

With our surgical refinement technique a thoroughly mobilized arytenoid cartilage can be brought to a physiologically abducted position with the previously described tilting manuever, and lateropexy through the vocal process can be performed in this position. The fact that the dorsal part of the thyroid cartilage is thicker and in elderly patients often ossified, however, means a technical challenge as the needle cannot be pushed through without damage either to it or to the needle carrier instrument itself. One option to avoid this is reinforcing the stem of Lichtenberger's device with a steel sheath. This simple modification eases passing the needle through the cartilage considerably, enabling us to create the thread loop at the desired position. The maximally abducted position of the arytenoid cartilage and the easily controllable mild postoperative edema which is expected after the minor tissue trauma ensure an immediate wide glottis, hence tracheotomy is avoidable.

Our experience on bilateral recurrent nerve paralysis suggests (75) that long term results are negatively affected if the physiological movement of the joint is not considered during surgery. If a vocal cord is pulled simply sideways, the loop slips off the vocal process onto its softer, ligamentous part. The thread may cut into the vocal cord which may negatively affect 
later results. The voluntary laryngeal movement at swallowing and phonation means a more serious problem in cases of well innervated larynx with PGS. Furthermore, damage and scarring of the membraneous part of the vocal cord which participates in vibration may badly affect voice production. In contrast, if the loop stays on the vocal process by the suggested tilting manuever, a stable surface is ensured for arytenoid cartilage abduction and the anatomical structure of the vocal cord can be preserved. Hence our opinion is that the correct term for this method is 'endoscopic arytenoid lateropexy'.

Once laterofixation was abolished, laryngeal motion became physiological and voice quality got close to the patients' original voice in cases of stenoses not destroying the joint structure. This series on a large number of patients supports clinical observations, according to which temporary laterofixation can be done without causing lasting damage to laryngeal movements. Thus this procedure is a reliable treatment in the early, potentially reversible phase of a bilateral vocal cord paralysis for preventing suffocation.

Our experience is that laryngeal movement and voice production improved in many cases when the intracapsular scarry fixation had to be transected with the endolaryngeal scythe. One explanation for this may be that the joint surfaces are partially preserved or that a pseudojoint develops which more or less enables motion. Mitomycin-C may promote this process by reducing intracapsular scarring. A somewhat better movement regeneration was observed in our patients treated thus, but proving this needs further examinations.

A significiant restenosis which badly affected breathing was observed after surgery in 3 cases of severe, type IV. stenosis. In such cases further evaluation is necessary to determine whether to combine the method suggested with other endoscopic techniques (e.g. covering the wound with a local flap, endoscopic laminotomy etc.) or to perform a laryngotracheal reconstruction procedure with an external approach.

\subsection{A SUBJECTIVE QUALITY OF LIFE QUESTIONNAIRE FOR THE EVALUATION OF PEDIATRIC STENOSIS}

Quality of Life Questionnaires are self-administered instruments for measuring the patients impairments. Different scales were developed, they proved their reliability, so they were inserted into the diagnostic protocol in many fields. The Asthma Quality of Life Questionnaire (AQLQ) is widely used in pulmonology to measure the efficacy of asthma treatment (76). Sintonen's 15D Health-related Quality of Life Instrument is one of the most 
accepted scale (77), it has been already introduced in several specialities, from internal medicine to urology. His scale deals with 15 dimensions describing life: mobility, vision, hearing, breathing, sleepning, eating, speech, excretion, usual activities, mental function, discomfort and symptoms, depression, distress, vitality and sexual activity.

Only some out of these dimensions are supposed to be impaired in upper airway stenosis. Monnier chose breathing, eating, speech and averall satisfaction is his scales (44). We adapted his scale and introduced it.

In early childhood this QoL Questionnaire is almost the only tool describing the functional outcomes of pediatric surgeries. According to our experiences the QoL results correlated well with the patients' condition. This method proved its validity and sensitivity.

\subsubsection{Endoscopic complex management of laryngeal web}

Most glottic stenoses diagnosed in early childhood are congenital malformations. The larynx first appears around day 25 to 28 of gestation as an epithelial thickening along the ventral aspect of the foregut, called the respiratory primordium. As it develops, the respiratory diverticulum, an outpouching of the foregut lumen, grows into it. The respiratory diverticulum develops into the area of the primitive pharyngeal floor at the level of the future adult glottis. Cranial to this is the level of thepharyngeal floor, and it is the area between these two structures which forms the primitive laryngopharynx. The esophagus is separated from the developing respiratory system by the tracheoesophageal septum. The next stage involves obliteration of the ventral lumen of the primitive laryngopharyx to form the epithelial lamina. Dorsal to this is the pharyngoglottic duct, connecting the pharyngeal floor to the infraglottis. This will form the posterior glottis and the interarytenoid notch. Located anterior to the epithelial lamina is the laryngeal cecum, which becomes the laryngeal vestibule. At close to 8 weeks of gestation the epithelial lamina starts to recanalize, allowing the laryngeal cecum and pharyngoglottic duct to unite. Failure to recanalize may result in laryngeal webs or stenosis $(78,79)$.

Acquired laryngeal webs mainly appear as a consequence of laryngeal interventions. In our two cases previous $\mathrm{CO}_{2}$-laser excision of laryngeal papilloma led to this disease.

There are two separate classification systems for laryngeal webs. Benjamin proposed a staging system based on the location of the web within the larynx describing glottic, supraglottic, subglottic and interarytenoid stenoses (80). Cohen's type 1 defines an anterior 
web involving less than $35 \%$, type 2 involving 35-50\%, type $350-75 \%$, type $475-90 \%$ of the glottis (10).

The management of laryngo-tracheal stenosis is still a great challange. Nowadays laryngotracheal reconstruction (LTR) is believed to provide the best results for the problem. To avoid these demanding open surgical interventions minimally invasive endoscopic methods have been introduced. As our case also proved no single scar dissection provide satisfactory results because of the restenosis. Ünal reported about a 22-month-old child, he applied antiproliferative Mitomycin-C after laser transsection (58). Schweinfurth combined endoscopic transection with keel insertion (57). Hsueh applied silastic for lateralisation after removal of the scar (56).

In our cases the above mentioned minimally invasive endoscopic methods were combined. After $\mathrm{CO}_{2}$-laser scar transsection topical Mitomycin-C was applied, then a special silicon stent was inserted.

In this first case we used the modified Ejnell's extra-endolaryngeal suture technique to insert and fix the stent by controll of an operating microscope (47). In the other two cases ETGI was applied (VI). Our previous experiences proved that this method offered perfect fixation of the stent into the ideal position between the vocal folds and the knots of the fixating sutures in the subcutanous layer were safe. The stent we applied was a special combined silicone tube and sheet stent. It passed cranially and caudally through the wound surfaces, the flexible silicone sheet prevented the decubitus of laryngeal mucosa, but the tube in its axle provided stable fixating points for the sutures. Even swallowing movements could not remove it from its ideal position.

\subsubsection{Pediatric airway surgery for laryngo-tracheal stenoses}

In the 1960s the incidence of postintubational stenosis was more than $20 \%$, but it decreased rapidly to $1 \%$ because of the improvement of intubation technique. The presence of inspiratoric or sometimes biphasic stridor suggests the diagnosis, but despite this signs the upper airway stenoses are often late discovered. The chronic dyspnea leads to lack of excercise, overweight and finally to the deterioration of life quality. The disease is often misdiagnosed, so the children are thought to have other pulmonary diseases and treated inadequately. 
In our opinion it is necessary to perform immediately endoscopic examinations if postintubational sudden stridor develops (X). A new diagnostic tool can be the virtual bronchoscopy based on high-resolution CT scans (81).

As our cases proved, nowadays the glottic stenoses can be managed by endoscopic methods. The subglottic and tracheal stenoses mainly require open approaches. Endoscopic laser techniques have only a limited role only in mild cases because of the high risk of restenosis. The 'accepted' treatment is the laryngo-tracheal reconstruction: augmentation of the laryngotracheal complex by anterior and posterior midline incision of the cricoid and thyroid cartilages with insertion of costal cartilage grafts to expand the airway $(5,5,7,8,9,10,11,12)$. The patients have to be trachetomised and endoluminar stents are placed for weeks until healing.

The tracheal segment resection and end-to-en anasthomosis has been a safe, effective solution for tracheal stenoses since 1960s. Montgomery suggested the resection of the anterior arch of the cricoid cartilage in case of stenoses involving the cricoid, and tracheo-thyreocricopexy as reconstruction. In 1993 Monnier made modifications and adapted this method to the narrow and small pediatric airway anatomy (82).

In our clinic tracheal resection has been routinely used in adults since 1989 (64). The excellent results encouraged us to operate children as well (V). Our above mentioned techniques provide immediately stable, wide airways in older children, the intubation tube can be removed in the end or soon after the surgery. In young children the narrow subglottis often became edematous during the surgery, so decannulation can be done only after a couple of days. Monnier applied laryngo-tracheal stents for weeks in severe cases, and finally his decannulation rate was $93 \%$ (62). According to our experiences no stent application is required.

With the application of our last modification, the combined one-stage laryngotracheal reconstruction with crico-tracheal resection method the the indication could be extended to newborns as well. The really tiny airways can be augmented properly.

If a newborn have severe dyspnea at birth, he is intubated and after confirming the proper airway status this technique may be a good choice to perform as an EXIT (ex utero intrapartum treatment) procedure instead of tracheastomy (83).

Fortunately we met no severe postoperative complications, no lesion of the recurrent nerves. There is an increased risk of recurrent nerve dissection in case of high subglottic stenoses, but proper tracheal preparation, staying in close contact with the tracheal ring, may help to avoid this complication. 
Earlier it was thought that these kinds of resections might have interfered with the subsequent normal subglottic growth. This theory is now obsoleted. Experimental animal studies proved that that laryngo-tracheal surgery had no effect on the growing of the airways, no dystorsion, assimetry or tissue hypoplasia should be expected $(84,85)$. This has been confirmed clinically, we have not experienced during the follow-up any growing abnormality yet.

\subsection{A COMPLEX EVALUATION PANEL OF THE UPPER AIRWAY}

Different methods are used for the evaluation of the upper airway. Endoscopic examination may be performed in local anaeshesia, but a good patient's cooperation is required. In many cases and espeacially in childhood endoscopy has to be done in general anaesthesia, which has some diasadventages, the narcosis means an additional strain for the patients, and there may be a risk of destroying the previously reconstructed airway. In early childhood the objective measurements of breathing (saturation, $\mathrm{CO} 2$ levels, etc) are valuable diagnostic tools too.

Radiological imaging is useful as well, the high resolution MRI and CT scans describe the area, and 3D CT reconstructions may help in stenosis surgery planning (81). These interventions are expensive and computer tomography means a large radiation explosure which may increase the risk of malignancies (86). Repeated head CT examinations significantly increase the risk of radiation-induced cataract (87).

For the evaluation non-invasive, safe methods can be applied too. In our Clinic we have introduced a phoniatric protocol containing different subjective and objective measurements for the phoniatric evaluation of laryngeal surgical methods in Hungary. Smehak proved that endoscopic arytenoid lateropexy provided good voicing, besides the good functional result in breathing. His 'Standard Voice Panel' was introduced to the daily routine (21).

Spirometrical examination and QoL Questionnaire proved their efficacy in describing the status of the upper airway. According to our experiences the changes of the parameters correlated well to our clinical experiences. 


\section{CONCLUSIONS AND NEW RESULTS}

\subsection{SURGICAL ANATOMICAL MORPHOMETRIC STUDIES}

Our study proved that different surgical methods designed for enlarging of the compromised airway can be well-modellised on cadaver larynges. The applied simple evaluation method allows an objective statistical comparison of these techniques. These kinds of studies could be the basis of the ranging of new or modified surgical procedures. In our study the benefit of endoscopic arytenoid lateropexy could be well-demonstrated.

\subsection{EXPERIMENTAL MODEL FOR THE EVALUATION OF THE EFFICACY OF THE SPIROMETRIC PARAMETERS IN AIRWAY STENOSIS}

In our opinion it is really hard to set valuable reference inspiratory spirometric indices because of the large standard deviation.

The artificial stenosis study proved that real exertional dyspnea occurred only in case of over $50 \%$ stenosis. Based on these findings it is questionable whether Cotton-Myers Gr. I. stenoses shoul be operated or not!

PIF and FIV1 are the most sensitive parameters for the extrathoracal airway stenosis.

\subsection{PIF AS AN INDICATOR OF THE IMPROVEMENT IN A NEWLY DESIGNED SURGICAL PROCEDURE FOR GLOTTIS STENOSIS}

In PGS patients the changes of PIF values correlated to the clinical observations, so spirometry could prove the efficacy of our surgical method.

\subsection{A SUBJECTIVE 'QUALITY OF LIFE' QUESTIONNAIRE FOR THE EVALUATION OF PEDIATRIC STENOSES}

In childhood the applicability of traditional evaluation tools is limited. Quality of Life Questionnaire was found to be valuable in describing the airways. 


\subsection{A COMPLEX AIRWAY EVALUATION PANEL}

Our suggested complex non-invasive evaluation panel is focusing on the most important parameters describing airway stenosis.

The spirometric and 'QoL' tests are simple, non-invasive, time and resources consuming methods for the everyday practice. The efficacy of different surgical tecniques can be easily assessed and compared.

This new complex evaluation protocol was introduced in Hungary. 


\section{ACKNOWLEDGEMENTS}

Without help, support, and encouragement from several persons, I would never have been able to complete this work.

First of all, I would like to express my gratitude and thanks to my supervisor, Professor László Rovó for encouraging and supporting my work from the very beginning.

I wish to express my gratitude to Professor Jenő Czigner and Professor Jóri József, the former Heads of Department of Oto-Rhino-Laryngology, Head and Neck Surgery who introduced me to clinical work and provided me with the opportunity to begin my scientific career.

I would like to express my gratitude to Professor Béla Iványi, Head of Department of Pathology for providing me the opportunity to perform the cadaver morphomeric study.

I would like to express my gratitude to Dr. László Viharos, associate professor of Bolyai Institute for his valuable help in statistical analysis.

I am deeply indepted to my collegues, the members of our upper airway stenosis workgroup, especially to Dr. László Rovó and Dr. György Smehák for their cooperative work.

Thanks to my colleagues at the Department of Oto-Rhino-Laryngology, Head and Neck Surgery.

Last but not least, I wish to thank my family and friends for their constant support and encouragement. 


\section{REFERENCES}

I. Rovó L., Venczel K., Torkos A., Majoros V., Sztanó B., Jóri J.: Endoscopic arytenoid lateropexy for isolated posterior glottic stenosis. Laryngoscope. 2008 Sep;118(9):1550-5

II. Sztanó B., Rovó L., Jóri J.: Kisgyermekkori kongenitális eredetű elülső commissura szükület megoldása endoszkópos technikák kombinálásával. Fül-OrrGégegyógyászat 2009;55(3): 121-125

III. Rovó L., Venczel K., Torkos A., Majoros V., Sztanó B., Jóri J.: Az izolált hátsó commissura hegesedés megoldása endoszkópos kannaporc lateropexiával. Fül-orrgégegyógyászat 2009;55(1):34-40

IV. Sztanó B., Torkos A., Rovó L.: The combined endoscopic management of congenital laryngeal web. Int J Ped Otorhinolaryngology 2010;74: 212-215

V. Rovó L, Sztanó B, Tálosi Gy, Rácz K, Majoros V, Czigner J, Túri S, Jóri J: Gyermekkori subglotticus és tracheaszükületek szegmentreszekcióra épülő egy lépésben történő megoldása. Gyermekgyógyászat 2010;61(2):54-59

VI. Rovó L, Madani S, Sztanó B, Majoros V, Smehák G, Szakács L, Jóri J.: A new thread guide instrument for endoscopic lateropexy. Laryngoscope. 2010 Oct;120(10):2002-7

VII. Sztanó B., Szakács L., Smehák Gy., Madani S., Jóri J., Rovó L. Hangréstágító mütétek hatásosságának vizsgálata cadaver gégéken morphometriás módszerrel I. a hátsó commissura konfigurációjának változása. Fül-orr-gégegyógyászat 2011; 57(2):48-53

VIII. Rovó L, Madani S, Sztanó B, Majoros V, Smehák Gy, Szakács L, Jóri J: Új, fonalvezető eszköz az endoszkópos arytenoid lateropexia céljára (referátum). FülOrr-Gégegyógyászat 2011;57(1):47-48

IX. Sztanó B, Majoros V, Marek B, Rovó L: The evaluation of pediatric upper airways in spontaneous breathing. 81. Jahresversammlung der Deutschen Gesellschaft für HNO, Wiesbaden, 2010, presentation

X. Sztanó B, Szakács L, Madani S, Smehák G, Rovó L: Minimally invasive endoscopic arytenoid lateropexy as revision surgery for bilateral vocal cord impairment. 1st Congress of CE-ORL-HNS, Barcelona, 2011, presentation 
(1) Réthi A. Une nouvelle technique chirurgicale pour le traitement de la fixation bilaterale des cordes vocals. Laryngol Rhinol Otol 1955; 34: 464-72

(2) Lichtenberger G. Endoscopic microsurgical management of scars in the posterior commissure and interarytenoid region resulting in vocal cord pseudoparalysis. Eur Arch Otorhinolaryngol.1999;256(8):412-4.

(3) Pytel J., Péter J., Pytel Á. King-Schobel szerinti hangréstágító mütét a POTE Fül-OrrGégeklinika anyagában. Fül-Orr-Gégegyógyászat 1997; 43:150-161

(4) Evans J.N.G., Todd G.B.: Laryngotracheoplasty. J. Laryngol Otol 1974; 87: 589-597

(5) Cotton R.: Management of subglottic stenosis in infancy and childhood. Review of a consecutive series of cases managed by surgical reconstruction. Ann Otol Laryngol 1978;87: 649-657,

(6) Cotton R.T., Seid A.B.: Management of the extubation problem in premature child. Anterior cricoid split as an alternative to tracheotomy. Ann Otol Rhinol Laryngol 1980; 89: 508-511,

(7) Cotton R.T., Myer C.M. 3rd, Bratcher G.O., et al: Anterior cricoid split, 1977-1987. Evolution of a technique. Arch Otolaryngol Head Neck Surg 1988;114(11):1300-2

(8) Rutter MJ, Cotton RT. The use of posterior cricoid grafting in managing isolated posterior glottic stenosis in children. Arch Otolaryngol Head Neck Surg. 2004 Jun;130(6):737-9.

(9) Bailey M., Hoeve H., Monnier P.: Paediatric laryngotracheal stenosis: a consensus paper from three European centres. Eur Arch Otorhinolaryngol 2003; 260: 118-123

(10) Cohen SR.: Congenital glottic webs in children. Ann Otol Laryngol 1985; 94(Suppl 121): $1-16$,

(11) Milczuk H.A., Smith J.D., Everts E.C.: Congenital laryngeal webs: surgical managements and clinical embriology. Int J Pediatr Otorhinolaryngol 2000; 52: 1-9

(12) Wyatt M.E., Hartley B.E.J: Laryngotracheal reconstruction in congenital laryngeal webs and atresias. Otolaryngol Head Neck Surg 2005; 132: 232-8,

(13) Mau T, Pletcher SD, Cavanagh PW, Courey MS, Wang SJ. Minicricothyrotomy approach with fiberoptic guidance for management of posterior glottic stenosis. Laryngoscope 2007 Aug;117(8):1488-90.

(14) Maren AGD, Glover GW. A modified McNaught keel for posterior glottic stenosis. J Laryngol Otol 1973;87:695-8.

(15) Lichtenberger G. Open and endoscopic surgical techniques for the treatment of scarred laryngeal stenosis. Otolaryngol-Head Neck Surg 1998; 9(3):150-153 
(16) Dedo HH, Sooy CD. Endoscopic laser repair of posterior glottic, subglottic and tracheal stenosis by division or micro trapdoor flap. Laryngoscope 1984;94:445-50.

(17) Hartnick C.J., Hartley B.E.J., Lacy P.D., Liu J., Bean J.A., Willging J.P.: Topical mitomycin aplication after laryngotracheal reconstruction. Arch Otolaryngol Head Neck Surg 2001; 127: 1260-4

(18) Roh JL. Prevention of posterior glottic stenosis by mitomycin C. Ann Otol Rhinol Laryngol. 2005;114(7):558-62.

(19) Lichtenberger Gy., Kaszás Zs., Reményi Á.: EMG, Mitomycin-C és endoextralaryngealis varrattechnika jelentősége a commissura posterior stenosis kezelésében. Fül-, Orr-, Gégegyógyászat 2005;51(2): 56-60,

(20) Myer C.M., O’Connor D.M., Cotton R.T.: Proposed grading system for subglottic stenosis based on endotracheal tube sizes. Ann Otol Rhinol Laryngol 1994; 103:319323

(21) Smehák G: Complex voice measurement panel for the assessment of the functional evaluation of the laryngeal surgical interventions. PhD Thesis, Szeged 2010

(22) Sellars I., Sellars S. Cricoarytenoid joint structure and function. The Journal of Laryngology and Otology 1983; 97:1027-1034

(23) Sonneson B. Die Functionelle Anatomie Des Cricoarytenoidgelenkes. Z Anat Entwickl 1959; 121:292-302

(24) Bogdasarian RS, Olson NR. Posterior glottic laryngeal stenosis. Otolaryngol Head Neck Surgery 1980;18:765-772

(25) Whited RE. Posterior comissure stenosis post long-term intubation. Laryngoscope 1983;93:1314-18.

(26) Whited E.R. Laryngeal dysfunction following prolonged intubation. Ann Otol 1979; $88: 474-478$

(27) Sapundzhiev N, Lichtenberger G, Eckel HE, Friedrich G, Zenev I, Toohill RJ, Werner JA. Surgery of adult bilateral vocal fold paralysis in adduction: history and trends. Eur Arch Otorhinolaryngol 2008 Dec; 265(12):1501-14.

(28) Schobel H. Dilatation of the glottis in bilateral vocal cord paralysis. Review of various surgical procedures and a report of personal experience using a functional lateral fixation surgical technic. HNO 1986; 34(12):485-95

(29) Laccourreye O, Paz Escovar MI, Gerhardt J, Hans S, Biacabe B, Brasnu D. CO2 laser endoscopic posterior partial transverse cordotomy for bilateral paralysis of the vocal fold. Laryngoscope 1999 Mar; 109(3):415-8. 
(30) Dennis DP, Kashima H. Carbon dioxide laser posterior cordectomy for treatment of bilateral vocal cord paralysis. Ann Otol Rhinol Laryngol. 1989 Dec;98(12 Pt 1):930-4.

(31) Crumley RL. Endoscopic laser medial arytenoidectomy for airway management in bilateral laryngeal paralysis. Ann Otol Rhinol Laryngol. 1993;102(2):81-4.

(32) Eckel HE, Wittekindt C, Klussmann JP, Schroeder U, Sittel C. Management of bilateral arytenoid cartilage fixation versus recurrent laryngeal nerve paralysis. Ann Otol Rhinol Laryngol. 2003 Feb;112(2):103-8.

(33) Woodson B.T., McFadden E.A., Toohill R.J. Clinical experience with the Lichtenberger Endo-Extralaryngeal Needle Carrier. Laryngoscope 1991; 101:1019-23

(34) Zalzal G.H. Posterior glottic fixation in children. Ann Otol Rhinol Laryngol 1993; 102: $680-6$

(35) Jóri J., Rovó L., Czigner J. Endolaryngeal laterofixation versus tracheostomy for treatment of acute bilateral vocal chord paralyses. Magyar Sebészet 1997; 50: 227-229

(36) Rovó L., Jóri J., Brzózka M., Czigner J. The treatment of bilateral vocal cord pseudoparalysis by $\mathrm{CO} 2$ laser excision and vocal cord laterofixation without tracheostomy. Congress of ELS, Roma Pontificia Universita Urbaniana 23-26 sept. 1998.

(37) Rovó L., Brzozka M., Czigner J. Airway complication after thyroid surgery: minimally invasive management of bilateral recurrent nerve injury. Laryngoscope 2000; 110(1):140-4

(38) Sztanó B, Rovó L, Smehák G, Jóri J. Endoscopic arytenoid lateralisation of scary fixed vocal cords. Eur Arch Otorhinolaryngol 2007; 264: Supplement 1

(39) Singh T., Sandulache V.C., Otteson T.D., Barsic M., Klein E.C., Dohar J.E., Hebda P.A. Subglottic stenosis (SGS) examined as a fibrotic airway mucosal response to injury characterized by altered mucosal fibroblast activity. Arch Otolaryngol Head Neck Surg. 2010; 136(2): 163-170.

(40) Rabe KF, Hurd S, Anzueto A, et al: Global strategy for the diagnosis, management, and prevention of chronic obstructive pulmonary disease: GOLD executive summary. Am J Respir Crit Care Med. 2007; 176: 532-55.

(41) Liang BM, Lam DCL, Feng YL: Clinical applications of lung function tests: a revisit. Respirology 2012

(42) Cantarella G, Fasano V, Bucchioni E, Domenichini E, Cesana BM: Spirometric and plethysmographic assessment of upper airway obstruction in laryngeal hemiplegia. Ann Otol Rhinol Laryngol. 2003 Dec;112(12):1014-20. 
(43) Kashima HK: Documentation of upper airway obstruction in unilateral vocal cord paralysis: flow-volume loop studies in 43 subjects. Laryngoscope 1984; 94:923-37

(44) Jaquet Y, Lang F, Pilloud R, Savary M, Monnier P: Partial cricotracheal resection for pediatric subglottic stenosis: Long-term outcome in 57 patients. Thorac Cardiovasc Surg 2005;130:726-32

(45) Ikonomidis C, George M, Jaquet Y, Monnier P: Partial cricotracheal resection in children weighing less than 10 kilograms. Otolaryngology Head and Neck Surgery.2010;142:41-47

(46) Lichtenberger G. Reversible lateralization of the paralyzed vocal cord without tracheostomy. Ann Otol Rhinol Laryngol. 2002 Jan;111(1):21-6.

(47) Ejnell H, Mansson I, Hallén O, Bake B, Stenborg R, Lindström J. A simple operation for bilateral vocal cord paralysis. Laryngoscope 1984 Jul; 94(7):954-8.

(48) Ossoff RH, Sisson GA, Duncavage JA, Moselle HI, Andrews PE, McMillan WG. Endoscopic laser arytenoidectomy for the treatment of bilateral vocal cord paralysis. Laryngoscope. 1984 Oct;94(10):1293-7.

(49) Koltai P., Ellis B., Chen J., et al: Anterior and posterior cartilage graft dimensions in successful laryngotracheal reconstruction. Arch Otolaryngol Head Neck Surg. 2006;132(6):631-4

(50) Rimmel FL, Dohar JE. Endoscopic management of pediatric posterior glottic stenosis. Ann Otol Rhinol Laryngol 1998;107:285-290

(51) Gaboriau H, Laccourreye O, Lacourreye H. Co2 laser posterior transverse cordotomy for isolated type IV posterior glottic stenosis. Am J Otolaryngol 1955;16:350-3.

(52) Rovó L, Jóri J, Brzozka M, Czigner J. Minimally invasive surgery for posterior glottic stenosis. Otolaryngology-Head and Neck Surgery 1999;121:153-156.

(53) Roh JL, Lee YW, Park HT. Effect of acid, pepsin, and bile acid on the stenotic progression of traumatized subglottis. Am J Gastroenterol. 2006;101(6):1186-92.

(54) Rovó L, Jóri J, Brzózka M, Czigner J. The treatment of bilateral vocal cord pseudoparalysis by $\mathrm{CO} 2$ laser excision and vocal cord laterofixation without tracheostomy. Eur Arch Otolaryngol. 1998; Suppl. 1:137.

(55) Lichtenberger G: Endo-extralaryngeal needle carrier instrument. Laryngoscope 1983;93:1348-1350

(56) Hsueh J.Y., Tsai C.S.S., Hsu H.T.: Intra-laryngeal approach to laryngeal web using lateralisation with silastic. Laryngoscope 2000; 110:1780-1782 
(57) Schweinfurth J.: Single-stage, stentless endoscopic repair of anterior glottic webs. Laryngoscope 2002;112:933-935,

(58) Ünal M.: The successful management of congenital laryngeal web with endocopic lysis and topical Mitomycin-C. Int J Pediatr Otorhinolaryngol 2004;68:231-235

(59) Bailey M., Hoeve H., Monnier P.: Paediatric laryngotracheal stenosis: a consensus paper from three European centres. Eur Arch Otorhinolaryngol 2003;260:118-123

(60) Monnier P., George M., Monod M.L., et al.: The role of the CO2 laser in the management of laryngotracheal stenosis: a survey of 100 cases. Eur Arch Otorhinolaryngol 2005;262(8):602-8

(61) Cotton R.T.: Management of subglottic stenosis in infancy and childhood. Rewiew of a consecutive series of cases managed by surgical reconstruction. Ann Otol Laryngol 1978;87:649-657

(62) Monnier P., Lang F., Savary M.: Partial cricotracheal resection for pediatric subglottic stenosis: a single institution's experience in 60 cases. Eur Arch Otorhinolaryngol 2003;260: 295-297

(63) Vollrath M., Freihorst J., Von der Hardt H.: Die chirurgie der erworbenen Laryngotrachealen Stenosen im Kindesalter. Erfahrungen und Ergebnisse von 19881998. Teil II: Die cricotracheale resection. HNO 1999;47:611-623

(64) Czigner J.: A laryngotrachealis stenosis modern sebészete lézerrel és harántrezekcióval. Fül-,Orr-,Gégegyógyászat 2004;50(1):14-21

(65) Czigner J., Rovó L., Brzozka M.: Circumferential resection of crico-tracheal stenosis with primary end-to-end anastomosis. Otolaryngol Pol 2004;58(1):149-155

(66) Brzózka M., Majoros V., Rovó L., et al: Supraglottikus jet lélegeztetés felsőlégúti szükületek mütéteihez. Aneszteziológia és Intenzív Terápia 2004;34:23-26,

(67) Eckel HE, Sittel C. Morphometric studies at the level of the glottis as a principle in larynx enlarging microlaryngoscopic surgical procedures in bilateral recurrent nerve paralysis]. Laryngorhinootologie 1994 Aug; 73(8):417-22.

(68) Sellars IE, Keen EN. The anatomy and movements of the cricoarytenoid joint. Laryngoscope 1978;88:667-74

(69) Von Leden H, Moore P. The mechanics of the cricoarytenoid joint. Arch Otolaryngol 1961;73:541-550.

(70) Rovó L., Madani S., Tóth F., Kiss J.G. Digital image analysis of the motions of the cricoarytenoideal joint. (A cricoarytenoidealis ízület mozgásának vizsgálata digitális képelemzéssel). Fül-Orr-Gégegyógyászat 2002; 48(4):244-250 
(71) Wang R. Three-dimensional analysis of cricoarytenoid joint motion. Laryngoscope 1998; 108 suppl.

(72) Vössing M, Wassermann K, Eckel HE, Ebeling O: Peak flow measurement in patients with laryngeal and tracheal stenoses. A simple and valuable spirometric method. HNO. 1995 Feb;43(2):70-5.

(73) Piersol G. Human Anatomy. London: Lippincott; 1907:1816.

(74) Neuman TR. Hengesteg A, Kaufman KR, et al. Three-dimensional motion of the arytenoid adduction procedure in cadaver larynges. Ann Otol Rhinol Laryngol 1994;103:265-70.

(75) Rovó L, Brzozka M, Czigner J. Airway complication after thyroid surgery: minimally invasive management of bilateral recurrent nerve injury. Laryngoscope 2000;110(1):140-4.

(76) Juniper EF, Guyatt GH, Epstein RS, Ferrie PJ, Jaeschke R, Hiller TK. Evaluation of impairment of health-related quality of life in asthma: development of a questionnaire for use in clinical trials. Thorax 1992;47:76-83

(77) Sintonen H. An approach to measuring and valuing health states. Soc Sci Med 1981;15C: 55-65

(78) Henick D.H., Holinger L.D.:Laryngeal development, in: L.D. Holinger, R.p. Lusk, C.G. Green (Eds.), Pediatric Laryngology and Bronchooesophagoscopy, LippincottRaven, Philadelphia, 1997

(79) Zaw-Tun HI.: Development of congenital laryngeal atresias and clefts. Ann Otol Rhinol Laryngol 1988;97:353-8,

(80) Benjamin B.: Congenital laryngeal webs. Ann Otol Rhinol Laryngol 1983; 92:317-26,

(81) Vass G, Rovó L, Smehák Gy, Kiss I, Jóri J: Virtuális endoszkópia: új módszer a felső légúti szükületek diagnosztikájában. Fül-, Orr-, Gégegyógyászat 2007; 53(3):119-124

(82) Monnier P, Savary M, Chapuis G.Partial cricoid resection with primary tracheal anastomosis for subglottic stenosis in infants and children. Laryngoscope. 1993 Nov; 103:1273-83.

(83) Bouchard S, Johnson MP, Flake AW, Howell LJ, Myers LB, Adzick NS, Crombleholme TM. The EXIT procedure: experience and outcome in 31 cases. J Pediatr Surg. 2002 Mar;37(3):418-26.

(84) Ciprandi G., Nicollas R., Triglia J.M., et al: Fetal cricotracheal manipulation: effects on airway healing, cricoid growth and lung development. Pediatr Surg Int 2003; $19(5): 335-339$ 
(85) Prince M.E., Nasser J.G., Pass B.B.: Effect of upper-airway passages on craniofacial growth in an animal model: a pilot study. J Otolaryngol 1997;26(5):306-15

(86) Pearce MS, Salotti JA, Little MP, McHugh K, Lee C et al. Radiation exposure from CT scans in childhood and subsequent risk of leukaemia and brain tumours: a retrospective cohort study. Lancet. 2012 Aug 4;380(9840):499-505

(87) Michel M, Jacob S, Roger G, Pelosse B, Laurier D, Le Pointe HD, Bernier MO. Eye lens radiation exposure and repeated head CT scans: A problem to keep in mind. Eur J Radiol. 2012 Aug;81(8):1896-900 


\section{APPENDIX}

'Quality of life' - Felső légúti szúkület

\begin{tabular}{|l|l|}
\hline Név: & Kórtörténet \\
\hline TAJ: & \\
\hline Dg: & \\
\hline Dátum: & \\
\hline
\end{tabular}

\section{Spirometria}

\begin{tabular}{|l|l|l|l|l|l|l|}
\hline PIF & FIV1 & FIVC & PEF & FEV1 & FEVC & Dátum \\
\hline & & & & & & \\
\hline & & & & & & \\
\hline & & & & & & \\
\hline & & & & & & \\
\hline
\end{tabular}

QoL kérdőív

\begin{tabular}{|c|c|c|c|c|c|c|c|}
\hline $\begin{array}{c}\text { Nehézlégzés } \\
1-5\end{array}$ & $\begin{array}{c}\text { Hangos légzés } \\
1-5\end{array}$ & $\begin{array}{c}\text { Köhögés } \\
1-4\end{array}$ & $\begin{array}{c}\text { Hang } \\
1-4\end{array}$ & $\begin{array}{c}\text { Nyelés } \\
1-3\end{array}$ & $\begin{array}{c}\text { Elégedettség } \\
1-4\end{array}$ & $\begin{array}{c}\text { Össz. } \\
6-24\end{array}$ & Dátum \\
\hline & & & & & & & \\
\hline & & & & & & & \\
\hline & & & & & & & \\
\hline
\end{tabular}

Endoscopia (dátum, felvétel helye) 